
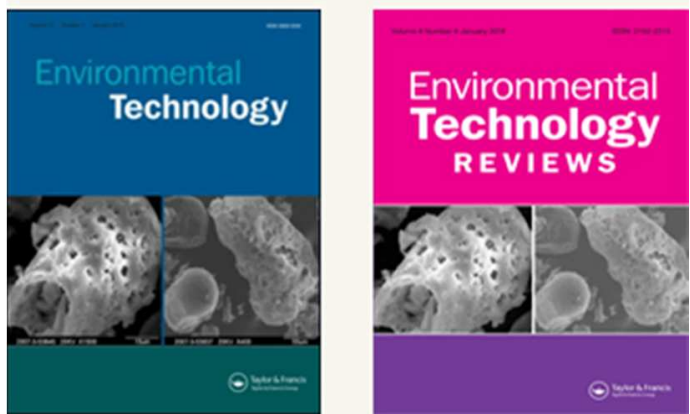

\title{
Chemical simulation of greywater
}

\begin{tabular}{|r|l|}
\hline Journal: & Environmental Technology \\
\hline Manuscript ID & TENT-TENT-2015-1182.R1 \\
\hline Manuscript Type: & Original Article \\
\hline Date Submitted by the Author: & n/a \\
\hline Complete List of Authors: & $\begin{array}{l}\text { Abed, Suhail; The University of Salford, } \\
\text { Scholz, Miklas ; The University of Salford, }\end{array}$ \\
\hline Keywords: & Sustainability, Ecosystem, Greywater, Synthetic greywater, Contamination \\
\hline
\end{tabular}

SCHOLARONE ${ }^{m}$

Manuscripts 


\title{
Chemical simulation of greywater
}

\author{
Suhail Najem Abed, Miklas Scholz* \\ Civil Engineering Research Group, School of Computing, Science and Engineering, The \\ University of Salford, Newton Building, Salford M5 4WT, England, United Kingdom. \\ * Corresponding author. Tel.: +44 161 2955921; fax: +44 161 2955575. Email: \\ m.scholz@salford.ac.uk (Miklas Scholz). \\ Email: suhail.najem@gmail.com (Suhail N. Abed).
}




\section{Chemical simulation of greywater}

Sustainable water resources management attracts considerable attention in today's world. Recycling and reuse of both wastewater and greywater are becoming more attractive. The strategy is to protect ecosystem services by balancing the withdrawal of water and the disposal of wastewater. In the present study, a timely and novel synthetic greywater composition has been proposed with respect of the composition of heavy metals, nutrients and organic matter. The change in water quality of the synthetic greywater due to increasing storage time was monitored to evaluate the stability of the proposed chemical formula. The new greywater is prepared artificially using analytical grade chemicals to simulate either low (LC) or high (HC) pollutant concentrations. The characteristics of the synthetic greywater were tested (just before starting the experiment, after two days and a week of storage under real weather conditions) and compared to those reported for real greywater. Test results for both synthetic greywater types showed great similarities with the physiochemical properties of published findings concerning real greywater. Furthermore, the synthetic greywater is relatively stable in terms of its characteristics for different storage periods. However, there was a significant $(\mathrm{p}<0.05)$ reduction in 5-day biochemical oxygen demand $\left(\mathrm{BOD}_{5}\right)$ for both low (LC) and high $(\mathrm{HC})$ concentrations of greywater after two days of storage with reductions of $62 \%$ and $55 \%$, respectively. A significant $(\mathrm{p}<0.05)$ change was also noted for the reduction $(70 \%)$ of nitrate-nitrogen $\left(\mathrm{NO}_{3}-\mathrm{N}\right)$ concerning $\mathrm{HC}$ greywater after seven days of storage.

Keywords: Sustainability; Ecosystem; Greywater; Synthetic greywater; Contamination

\section{Introduction}

\section{Background}

Researchers estimate that one-third of the world population could have insufficient water resources by 2025 [1]. Therefore, recycling of wastewater for non-portable purposes has been considered as a new strategy to conserve conventional water 
resources [2]. The most common practises of recycling treated wastewater and greywater can be found in the agricultural, industrial, urban and environmental sectors $[3]$.

Greywater is a major proportion of domestic wastewater (around 50 to 80\%) [4], which is generated from all household wastewater streams, except toilet discharge $[2,4,5]$. However, some literature has excluded the flow contributions of kitchen sinks, garbage disposal units and/or dishwashers from greywater [6,7,8,9]. High fluctuations in quality and a considerable overlap in characteristics between black and grey wastewater have been reported [4]. The compounds present in greywater vary from source to source, and depend on different lifestyles, customs and installations as well as on the use of chemical household products [6]. Furthermore, there could be chemical and biological degradation of the chemical compounds within the transportation network and during storage affecting physical and chemical parameters $[4,10,11]$.

Reported physiochemical parameters of particular relevance for greywater are summarized in Table 1. Food particles and raw animal fluids from kitchen sinks, soil particles as well as hair and fibres from laundry wastewater are examples of sources of solid material in greywater [4]. High temperatures may be unfavourable since they enhance microbial growth and could induce precipitation in supersaturated solutions [7].

Measurements of turbidity and suspended solids provide some information concerning the overall content of particles and colloids that could induce clogging of installations such as the piping used for greywater transportation as well as sand filters and constructed wetlands used for subsequent treatment [4]. Measurements of the traditional wastewater parameters 5-day biochemical oxygen demand $\left(\mathrm{BOD}_{5}\right)$, chemical oxygen demand (COD) and nutrients such as nitrogen $(\mathrm{N})$ and phosphorus $(\mathrm{P})$ in form of ammonia-nitrogen $\left(\mathrm{NH}_{4}-\mathrm{N}\right)$, nitrate-nitrogen $\left(\mathrm{NO}_{3}-\mathrm{N}\right)$ and ortho-phosphate- 
phosphorus $\left(\mathrm{PO}_{4}-\mathrm{P}\right)$ also give valuable information about the chemistry of greywater [18]. Ramona et al. [14] argued that wastewater would be better classified as a function of pollution load rather than origin, and hence suggesting the notion of low (bath, shower and washbasin) and high (kitchen, washing machine and dishwasher) strength greywater.

A major difficulty when treating greywater is the considerable variation in its composition. Reported mean values of, for example, $\mathrm{COD}$ and $\mathrm{BOD}_{5}$, vary from 40 to $371 \mathrm{mg} / \mathrm{l}$ and from 33 to $466 \mathrm{mg} / \mathrm{l}$, respectively, between sites and with similar variations arising at an individual site $[4,6,14,20]$. This has been attributed to changes arising in the quantity and type of detergent products employed during washing. Moreover, significant chemical changes may take place over time periods of only a few hours [2]. Among other pollutants, trace elements and heavy metals have been reported as important components to take into consideration for treatment, storage and recycling purposes as indicated in Tables 2 and $3[16,19]$.

\section{Storage of greywater}

The $\mathrm{BOD}_{5}$ and dissolved oxygen (DO) concentrations decrease during the sedimentation period when greywater is stored. Evidence has shown that $50 \%$ removal of $\mathrm{BOD}_{5}$ could be achieved when greywater is stored over a four-hour-period [2].

However, extended storage may lead to the risk of odour increases and possibly health issues due to enhanced microorganism growth [22]. Furthermore, the $\mathrm{BOD}_{5}$ concentration in, for example, greywater washing hand basins has been reported as being slightly lower than the one generated from mixed resources as well it varies with different discharge patterns [6]. 
There has been considerable research into the quality processes of raw greywater occurring during the storage stage [23]. For example, Dixon et al [24] indicated improvements in greywater quality during complex storage processes.

\section{Reported synthetic greywater}

In general, recycling of greywater is widely accepted compared to blackwater due to the lack of urine and faeces in the former [25]. So, the pathogens and nutrients occurring in greywater are present in much lower concentrations than in blackwater [4].

Greywater does not contain the right nutrient and trace element ratio required for standard biological treatment or advanced treatment by membrane bioreactor $[6,10,22]$. Furthermore, low concentrations of trace elements have been linked to greywater [4]. Some synthetic greywaters have been created by mixing different recipes of chemical products that household use and/or analytical grade chemicals known to be present in real greywater. Consequently, these chemicals are expected to control the characteristics of the generated greywater in terms of water quality [26].

Nghiem et al. [17] investigated the feasibility of submerged ultrafiltration technology applied for greywater recycling. The synthetic greywater solution contained kaolin, cellulose, humic acid, sodium hypochlorite, calcium chloride electrolyte and a sodium bicarbonate buffer. These materials were also used in combination with sodium dodecyl sulphate to represent synthetic greywater proposed by Schäfer et al. [26].

Nazim and Meera [27] studied the treatment ability of a synthetic greywater by adding different concentrations of an enzyme protein solution to examine the reduction of chemical variables including nutrients. The mixture of synthetic greywater contained glucose, sodium acetate trihydrate, ammonium chloride, disodium hydrogen phosphate, potassium dihydrogen phosphate, magnesium sulphate and cow dung. 
Diaper et al. [28] introduced a synthetic greywater recipe to simulate combined laundry and bathroom greywater from an Australian residential dwelling. The constituents of the greywater included a variety of personal hygiene and household products, some laboratory grade chemicals (sodium dodecyl sulphate, sodium hydro carbonate, sodium phosphate, boric acid, and lactic acid), and secondary sewage effluent sourced from a local wastewater treatment plant.

Fenner and Komvuschara [29] described a new approach to model the effect of factors influencing ultraviolet disinfection efficiency of real and synthetic greywaters. A range of synthetic greywater recipes has been developed for both soft and hard waters to ensure they were representative of the properties of real greywater samples. A typical synthetic greywater recipe comprised dextrin, ammonia chloride $\left(\mathrm{NH}_{3} \mathrm{Cl}\right)$, yeast extract, soluble starch, sodium carbonate $\left(\mathrm{Na}_{2} \mathrm{CO}_{3}\right)$, monosodium phosphate $\left(\mathrm{NaH}_{2} \mathrm{PO}_{4}\right)$, potassium phosphate $\left(\mathrm{K}_{2} \mathrm{PO}_{4}\right)$ and an Escherichia coli culture mixed with distilled water.

Surendran and Wheatley [3] proposed a biological treatment process for greywater obtained from large buildings. The synthetic greywater used comprised a known amount of soap, detergent, starch yeast extract and cooking oil. Settled sewage was also added to provide appropriate bacteria counts.

Jefferson et al. [22] dosed synthetic and real greywater with nutrient supplements. The synthetic greywater recipe comprised synthetic soap, hair shampoo, sunflower oil and tertiary effluent.

Gross et al. [30] have developed a new small-scale vertical-flow constructed wetland for decentralized treatment of greywater. The removal of indicator and pathogenic microorganisms was investigated to assess the reuse of treated greywater for irrigation purposes. The focus was on the removal dynamics of Escherichia coli, 
Staphylococcus aureus and Pseudomonas aeruginosa in three different synthetic greywaters.

Each greywater was made by combining three waste stocks representing laundry, bath and kitchen wastes [30]. The composition of synthetic greywater for each stock contained laundry soap, shampoo, cooking oil, and kitchen effluent (comprising one egg and one tomato). All greywater types were supplemented with raw sink effluent from a large dining room. This effluent, which contained an inoculum of E. coli and other bacteria, was added in a small enough volume not to affect the composition of the synthetic greywater [31].

In a controlled study, a recirculating vertical-flow constructed wetland has been investigated to assess the effect of irrigation with treated greywater on soil properties [32]. The greywater was prepared according to a similar recipe used by Gross et al. [31]. However, pulverized bar soap was applied instead of shampoo in the synthetic greywater.

Gross et al. [20] developed an economically sound, low-tech and easily maintainable combined vertical-flow constructed wetland and trickling filter system for greywater treatment and subsequent recycling. The greywater was prepared artificially by mixing laundry detergent, boric acid and raw kitchen effluents into tap water.

Comino et al. [33] proposed a functional hybrid phytoremediation pilot platform for the treatment of greywater. The pilot plant was tested with and without vegetation for different design specifications as well as for various organic and hydraulic loads of synthetic greywater. This study by Comino et al. [33] followed one by Gross et al. [20] in terms of preparation of artificial greywater.

Glasshouse experiments were conducted by Pinto et al. [34] to understand the effects of greywater reuse for irrigation of plants. Changes in soil $\mathrm{pH}$, electric 
conductivity and nutrient content (total nitrogen and total phosphorus) due to greywater irrigation were assessed. Synthetic greywater was prepared by mixing a commonly available local detergent with potable water.

Winward et al. [35] evaluated the three treatment technologies constructed wetlands, membrane bioreactors and membrane chemical reactors for indicator microbial removal and greywater reuse potential under conditions of low and high strength greywater influents. A high strength supplementary solution together with real greywater was pumped to the treatment systems. Real greywater was referred to as low or high strength solution based on a mixture of locally sourced shampoo diluted by tap water.

\section{Chemicals used in greywater simulation}

The increased focus on the treatment and reuse of highly variable real greywater has driven some researchers to create greywater with stable properties artificially as indicated in Table 4a [36]. The concentrations of the corresponding greywater pollutants (e.g., organic strength, nitrogen, phosphorus, surfactants and metals) as a result of mixing the ingredients listed have been published in the references shown in Table $4 \mathrm{a}$. Table $4 \mathrm{~b}$ shows the corresponding water quality. However, most recipes cannot be reproduced accurately, because the environmental boundary conditions are variable or unreported. Moreover, some ingredients such as cow dung, shampoo and kitchen effluent is unspecified. A reproduction of the published water quality data is therefore of little use to the readers of this paper. Nevertheless, a review of the most common chemicals used for artificial greywater recipes is summarized below.

Kaolin is a common clay mineral composed of alternating sheets of aluminium hydroxide and silicate [38]. It is frequently selected as an artificial greywater 
component to represent suspended organic and inorganic solids in greywater, which may originate from natural clay containing various mineral components. These solids are often generated from kitchen and laundry effluents [4]. Kaolin is also used in synthetic wastewater recipes $[17,26,39,40]$.

Cellulose is the principal structural component of plant cells and leaves. Furthermore, the majority of the carbohydrates found in soils are derived from cellulose, which is one of many polymers found in nature [38]. Cellulose is frequently chosen to mimic organic fibres in greywater, since kitchen sinks and dishwashers are common sources of organic fibres $[17,26]$.

All natural waters contain humic [38] constituents as the result of biodegradation of animal and plant matter or might form in situ due to the presence of soils, nutrients, and cellulosic substrates for microbial action in the waste [41]. Humic acid is often used to represent dissolved organic matter in greywater $[17,26]$.

Boric acid is frequently applied to represent boron ions in greywater. One source of boron is natural and the other is a result of human activities (e.g., extraction plant, industry and detergent containing sodium perborate). It follows that many water sources and wastewaters may contain boron in variable concentrations [20,28].

The following salts have been previously suggested as possible ingredients in synthetic greywater: Sodium chloride (dissolved monovalent salt) is found as a common ingredient of soap solutions and dyes [42,43]. Sodium hydrogen carbonate (natural buffer) and sodium dodecyl sulphate are mainly used for the manufacture of detergents. Their greatest cleaning application is as filler in powdered home laundry detergents $[43,44]$. Sodium hydrogen carbonate, sodium dodecyl sulphate and sodium phosphate are important in the manufacture of textiles by reducing negative charges on fibres, so 
that dyes can penetrate evenly [45]. Some of these salts have previously been used in synthetic grey and municipal wastewater recipes $[3,17,26,28,37,40]$.

Calcium nitrate and calcium chloride have been suggested as components in synthetic greywater. Calcium salts are chosen to provide calcium ions to artificial greywater. Previous research used calcium salts in synthetic greywater [17,26]. Laboratory grade chemicals such as potassium nitrate, mono-potassium phosphate and magnesium sulphate have been chosen in previous studies [27,37] to resemble real greywater in terms of nutrients and macronutrients generated from laundry and kitchen effluents. Low suspended solids and turbidity linked to greywater indicates that a large proportion of pollutants are dissolved. Although organics present in greywater are relatively similar to domestic greywater, their chemical natures are quite different. So, the deficiency of nutrients and low values of biodegradable organic matter are limiting the effectiveness of biological treatment of greywater [6].

Iron(III) chloride, manganese(II) chloride, chromium(III) nitrate, zinc sulphate, copper sulphate, cadmium oxide, nickel oxide, and lead(II) oxide are commonly selected to provide heavy metals to artificial greywater, as discussed in publications reported in Table 3. Sources of heavy metals in real greywater may be from cosmetics [16], other products such as skin emulsions (creams, lotion and jelly), soap, shampoo, hair cream, henna dye $[46,47]$ and from body parts such as hair, nails and died skin cells $[4,48]$.

Ammonium molybdate tetrahydrate is used to provide molybdenum in artificial greywater. Molybdate is also known to enhance the biological treatment of wastewater [22]. Sodium hydroxide and hydrochloride acid are widely used as buffers to adjust the $\mathrm{pH}$ value of a chemical solution. 
Small quantities of secondary or tertiary effluent obtained from predominantly domestic wastewater treatment plants is frequently recommended as an additive to synthetic greywater to provide a source of pathogens and microorganisms in general $[28,31,36,37,40]$. However, the addition of microbes might not be necessary for experiments in non-sterile environments such as outdoor trials where a microbial population adjusted to the system tested will establish naturally eventually. One target of this study is to evaluate the stability of chemical compositions of artificial greywater through specific storage time experiments, without the contribution of biological treatment, which is offered by micro-organism. There are numerous papers in the peerreviewed literature indicating greywater recipes that have no artificially introduced micro-organism in the list of ingredients $[17,26]$.

\section{Rationale, aim, objectives and scope}

There is a need to develop standard synthetic greywater recipes to allow for the easy comparison of similar experiments in the future. Original experiments and a detailed literature review have been performed to support the development of reasonably stable generic synthetic greywater recipes for both low and high concentrations.

The aim of this article is to propose practical recipes to be used for the simulation of greywater, which can be used with confidence to assess different treatment technologies. The objectives are (a) to review previous greywater recipes and corresponding components, (b) to evaluate the quality of the new synthetic greywater and compare it with recipes found in the literature, (c) to examine the stability of synthetic greywater as a function of time, and (d) to show that water quality changes are not caused by internal reactions of used chemicals. 
The scope of this paper is limited to weak and strong standard synthetic greywater recipe proposals being prepared under non-sterile conditions. It follows that specific greywater types, which are often a function of geographical region, cultural and religious practices as well as guidelines and legislation, are beyond the scope of this article.

\section{Materials and methods}

\section{Synthetic greywater}

Household greywater was created artificially by using analytical grade chemicals (Table 5) purchased from Fisher Scientific Co. Ltd. (Bishop Meadow Road, Loughborough, UK). The synthetic greywater was prepared under non-sterile conditions as a stock solution by mixing the selected chemicals with de-chlorinated public mains tap water at a temperature of around $25^{\circ} \mathrm{C}$. The following water quality parameters of greywater were simulated: biochemical oxygen demand, chemical oxygen demand, ammonianitrogen, nitrate-nitrogen, ortho-phosphate-phosphorus, $\mathrm{pH}$, redox potential, turbidity, total suspension solids and electronic conductivity. The resultant key pollutants of the proposed recipes are summarised in Table 6 .

Two stock solutions were mixed separately to represent low (LC) and high (HC) greywater strengths, and stirred by a magnetic stirrer $(3.0 \mathrm{~cm}$ long and $0.5 \mathrm{~cm}$ wide) with rounded edges for one hour at $1200 \mathrm{rpm}$ [26]. The two solutions were stored overnight at $4^{\circ} \mathrm{C}$, and stirred for a further 30 minutes before the start of subsequent experiments. The concentration levels of the proposed synthetic greywater are shown in Table 6. These concentrations were subject to environmental conditions typical for Greater Manchester (temperate and oceanic climate) between November and May. 
Sodium hydroxide $(\mathrm{NaOH})$ and hydrochloride acid $(\mathrm{HCl})$ were used to adjust the $\mathrm{pH}$ value of the solution [17]. A wide range for $\mathrm{pH}$ values for real greywater has been reported in literature (Table 1). However, in this experiment, the $\mathrm{pH}$ values for both low and high strength greywaters were adjusted at $\mathrm{pH}$ ranges of around 5 to 7 and 7 to10, respectively.

\section{Experimental set-up}

The set-up design includes two groups of black plastic buckets (volumes of 14 litres each) selected to store 10 litres of the prepared greywater for two days and seven days residence storage times. The storage times selected represent typical ones reported in literature (Tables 1 to 4). Moreover, there are rather practical considerations of regular feeding of experimental set-ups avoiding weekends. Each group has two bucket replicates; the first group was used for storing low concentration greywater and the second for keeping high strength greywater.

The buckets were subjected to real weather conditions at a quiescent place on University grounds from $1^{\text {st }}$ of November 2014 to $30^{\text {th }}$ of April 2015. Samples were collected manually after the specific storage time ( 2 and 7 days) to conduct several analytical tests as outlined in the next section.

\section{Water quality}

Water quality sampling was carried out according to APHA [49], unless stated otherwise, to monitor the properties of synthetic greywater. The spectrophotometer DR 2800 (Hach Lange, Rechnungen, Germany) was used for standard water quality analysis concerning variables including chemical oxygen demand (COD, mg/l), ammonianitrogen $\left(\mathrm{NH}_{4}-\mathrm{N}, \mathrm{mg} / \mathrm{l}\right)$, nitrate-nitrogen $\left(\mathrm{NO}_{3}-\mathrm{N}, \mathrm{mg} / \mathrm{l}\right)$, ortho-phosphate-phosphorus $\left(\mathrm{PO}_{4}-\mathrm{P}, \mathrm{mg} / \mathrm{l}\right)$, total suspension solids (TSS, mg/l) and colour $(\mathrm{Pa} / \mathrm{Co})$. 
The 5-day biochemical oxygen demand $\left(\mathrm{BOD}_{5}, \mathrm{mg} / \mathrm{l}\right)$ was determined in all water samples with the OxiTop IS 12-6 system, a mono-metric measurement device, supplied by the Wissenschaftlich-Technische Werkstätten (Weilheim, Germany). Turbidity was measured with a Turbicheck Turbidity Meter (Lovibond Water Testing, Tintometer Group, Dortmund, Germany). The redox potential (redox) was measured with a sensION+benchtop multi-parameter meter (Hach Lange, Düsseldorf, Germany). The electric conductivity $(\mathrm{EC}, \mu \mathrm{s} / \mathrm{cm})$ was determined by a conductivity Meter entitled METTLER TOLEDO FIVE GOTM (Keison Products, Chelmsford, Essex, England, UK). Dissolved oxygen (DO, mg/l) for all samples was measured by an HQ30d Flexi meter (Hach Lange, Düsseldorf, Germany).

\section{Data analysis}

Microsoft Excel has been used for the general data analysis (e.g., mean, standard deviation, minimum and maximum values). The non-parametric Mann-Whitney test was computed using IBM SPSS Statistics Version 20 and applied to compare the variance in test results of two (unmatched) independent samples. Since, all sample data were not normally distributed.

\section{Results and discussion}

\section{Synthetic greywater characteristics}

The inflow water parameters in Table 6 refer to characteristics of prepared synthetic greywater just before utilisation in the experiment. These parameters were compared and discussed with published results of real greywater constituents obtained from previous research studies (Table 1).

The figures shown in Table 6 are based on outside (greywater systems exposed 
to the elements) experiments. The data variability is therefore high, resulting in some unexpected findings, which are, however, not statistically $(\mathrm{p}>0.05)$ significant. For example, the mean COD of inflow (LC greywater) was $25.2 \mathrm{mg} / \mathrm{l}$. After two days of storage, the average outflow COD was $27.9 \mathrm{mg} / 1$. Furthermore, the corresponding standard deviations are relatively high and the sample numbers of both data sets are different.

There are very few reported data regarding colour of real greywater. The test results of synthetic greywater have shown ranges of colour from 26.0 to $332.0 \mathrm{~Pa} / \mathrm{Co}$ and from 787.0 to $2499.0 \mathrm{~Pa} / \mathrm{Co}$ for LC and HC greywater concentrations, respectively. The temperature was around $6.5-37.0^{\circ} \mathrm{C}$ for both types of proposed greywater, which was similar to figures reported by Eriksson et al. [4] and Christova-Boal et al. [7]. Depending on the sources of greywater, there is a wide range of $\mathrm{pH}$ for real greywater. Most of these waters were simulated by using LC synthetic greywater with a $\mathrm{pH}$ between 6.0 and7.9, while the $\mathrm{pH}$ values for $\mathrm{HC}$ greywater were between 5.4 and 11.5, representing those real discharges, which were commonly generated from laundries $[4,7,10,17]$.

The reported ranges for turbidity and total suspended solids (TSS) as shown in Table 1 were successfully simulated particularly by the ingredient kaolin (Table 5) for both greywater strengths (Table 6). Those values for simulated HC greywater (mean of $318 \mathrm{mg} / \mathrm{l}$ and range between $190 \mathrm{mg} / \mathrm{l}$ and $473 \mathrm{mg} / \mathrm{l}$; Table 6) are particularly represented by the solids in the discharges from laundry, kitchen and mixed greywater sources as shown in Table $1[4,7,10,12]$, while the simulated LC greywater (mean of 40 $\mathrm{mg} / \mathrm{l}$ and range between $10 \mathrm{mg} / \mathrm{l}$ and $87 \mathrm{mg} / \mathrm{l}$; Table 6) is linked to waters from hand basins, showers and similar mixed greywater sources as indicated in Table 1 $[6,13,14,15,16]$. Electric conductivity data for real greywater in literature have 
demonstrated high levels for laundry and mixed greywater sources [4,7,14,18]. In contrast, low values are linked to bathroom fluxes $[4,7,12,19]$. The DO was around the reported upper limits, especially in the absence of significant numbers of microorganism in the synthetic greywater.

Numerous water quality parameters of the proposed greywaters (Table 6) have similar values in terms of averages, or are at least within the published ranges (Tables 1 to 3$)$. Although the concentrations of $\mathrm{BOD}_{5}$ in low strength greywater, in particular, are less than some of the reported values for real greywater, but they agree with those indicated by Eriksson et al. [16] and Winward et al. [35].

The review on chemical oxygen demand (COD) concentrations in literature reveals that there is a wide variation of greywater types and compositions (Table 1). This can be explained by a great variety of household chemicals used causing a high degree of fluctuation from sample to sample $[4,6,16]$. Comparted with those obtained from the analysis of synthetic greywater (Table 6), the LC greywater COD concentrations were similar to the lower limits of reported studies. Furthermore, the test results for synthetic greywater (Table 6) have shown appropriate simulations for reported values of ammonia-nitrogen $\left(\mathrm{NH}_{4}-\mathrm{N}\right)$, nitrate-nitrogen $\left(\mathrm{NO}_{3}-\mathrm{N}\right)$ and orthophosphate-phosphorus $\mathrm{PO}_{4}-\mathrm{P}$, in terms of mixed greywater regardless the sources of origin $[4,13,14,16]$.

In the literature, various recipes for synthetic greywater, which was utilized for different treatment technologies, have been proposed (Table 4a). This study illustrates how to choose analytical grade chemicals to create two strength solutions of synthetic greywater (Table 5). Organic and inorganic matter, dissolved and suspended solids, nutrients and macronutrients, trace elements and microorganisms were resembled carefully to simulate real greywater components and associated properties. Depending 
on data shown in Table 2 and 3, synthetic greywater solutions represent reality reasonably well. The recipe was based on the molar weight of the chemical composition multiplied by the percentage of the specific element in that chemical. For example, 100 mg of Iron (III) chloride provides $34 \mathrm{mg} / 1$ of iron (Table 5).

\section{Stability of synthetic greywater}

Table 6 shows all water quality results of LC and HC synthetic greywaters after two and seven days of storage. For LC greywater, the $\mathrm{pH}$ has increased from 6.9 to 7.2 for a two-day storage period. There was no significant $(p>0.05)$ change after seven days of storage. However, data show a reduction in colour, turbidity and total suspended solids for the outflow of two-day storage experiments by $22.0 \%, 5.5 \%$ and $23.4 \%$, respectively. The percentages concerning the outflow for the seven-day storage experiments were $14.2 \%, 11.1 \%$, and $22.9 \%$, respectively. The number of colloids and particles is likely to reduce over time as physical (e.g., coagulation and flocculation) processes reduce turbidity and suspended solids. However, biochemical processes such as biodegradation will lead to an increase in microorganisms and debris contributing to an increase in turbidity and fine material $[4,7,10,20,24,30]$.

A statistical analysis has shown no significant $(\mathrm{p}>0.05)$ changes in colour, $\mathrm{pH}$, turbidity and total suspended solids, when both synthetic greywaters are stored for two or seven days. This confirms previous findings $[28,36]$ showing that suspended solids and insoluble particle concentrations of chemical greywaters are highly stability, possibly, because they originate from inert materials.

Figure 1(a) and (b) illustrate the variations in $\mathrm{BOD}_{5}$ concentrations for both $\mathrm{LC}$ and HC synthetic greywater, respectively. The values for LC greywater have shown significant $(\mathrm{p}<0.05)$ reductions in the averages from $15.2 \mathrm{mg} / 1$ to $5.7 \mathrm{mg} / \mathrm{l}$ and to 7.0 at 
two and seven days of storage time, respectively (Table 6 and Figure 2(a)). While for $\mathrm{HC}$ greywater, the biochemical oxygen demand has dropped significantly $(\mathrm{p}<0.05)$ form $32.3 \mathrm{mg} / \mathrm{l}$ to $14.5 \mathrm{mg} / \mathrm{l}$ after two days of storage with a reduction of $55.2 \%$, and it was stable at around $14.7 \mathrm{mg} / \mathrm{l}$ for outflow water after seven days (Table 6, Figure 2(a)). This change has been confirmed by comparing available data evidence, which was reported by Jefferson et al. [2]. Microbial contamination is the likely reason for the drop in organic strength $[50,51]$.

The chemical oxygen demand in the LC greywater increased from $25.2 \mathrm{mg} / 1$ to $27.9 \mathrm{mg} / \mathrm{l}$ (not statistically significant ( $\mathrm{p}>0.05$ ); see also above) for the two-day storage time experiment. However, it decreased to $19.6 \mathrm{mg} / \mathrm{l}$ for the seven-day storage time test (Figure 2(b)). In contrast, the chemical oxygen demand for HC greywater dropped from $115.4 \mathrm{mg} / \mathrm{l}$ to $110.7 \mathrm{~m} / \mathrm{l}$ (reduction by $4.1 \%$ ) and to $108.3 \mathrm{mg} / \mathrm{l}$ (reduction by $6.2 \%$ ) for two-day and seven-day storage times, respectively. The variations in test results are shown in Figures 1(c) and (d) in that order. Some of the COD data variations can be attributed to both experimental variability (see discussion in the previous section) and biodegradation of the fraction of the COD, which is biodegradable $[29,38]$.

For HC greywater, the averages of ammonia-nitrogen show a stable behaviour with values of around $0.4 \mathrm{mg} / \mathrm{l}$ without change through storage (Figures 1(e) and (f)). The corresponding values for LC greywater have decreased from $0.2 \mathrm{~m} / 1$ to $0.1 \mathrm{mg} / 1$ after two days of storage. The results show no change for seven days outflow (Figure 2(c)). The measured values for ammonia-nitrogen are close to the detection limit. Therefore, the transformation of ammonia to nitrite and subsequently to nitrate cannot be evidence in this experiment [38].

A considerable change was observed for the average values of nitrate-nitrogen after both storage times. The values dropped from $9.2 \mathrm{mg} / 1$ to $6.2 \mathrm{mg} / 1$ and $2.8 \mathrm{mg} / \mathrm{l}$ after 
storage times of tow and seven days, respectively (Table 6, Figure 1(h)). However, a significant $(\mathrm{p}<0.05)$ reduction was noted for two days of storage regarding HC synthetic greywater. In contrast, the nitrate-nitrogen values of LC greywater decreased slightly from $1.4 \mathrm{mg} / 1$ to 1.3 and to $1.1 \mathrm{mg} / \mathrm{l}$ after two and seven days of storage time in this order (Figures $1(\mathrm{~g})$ and 2(d)). The reduction of nitrate-nitrogen can be explained by denitrification [38].

Also, there are no significant $(\mathrm{p}>0.05)$ changes in the reduction of orthophosphate-phosphorus for both storage times (Figures 1(i) and (j)). They decreased from $50.6 \mathrm{mg} / 1$ to $46.5 \mathrm{mg} / \mathrm{l}$ (reduction of $8.2 \%$ ) for two-day storage, and decreased to $45.8 \mathrm{mg} / 1$ (reduction of $26.4 \%$ ) for seven-day storage of HC greywater. The orthophosphate-phosphorus concentrations also decreased from $6.3 \mathrm{mg} / 1$ to $5.6 \mathrm{mg} / \mathrm{l}$ for twoday storage experiments, and to $8.2 \mathrm{mg} / 1$ for seven-day storage of LC greywater (Figure 2(e)). Phosphorus is likely to be taken up by microbes developing in the outside systems [51]. However, considering that microbes were not deliberately added to the greywater recipe, microbial biomass development is rather slow. Therefore, changes in phosphorus concentrations were small.

\section{Conclusions and recommendations}

The proposed new synthetic greywater recipes mimic real greywater well in both composition and properties. Furthermore, they provide a good matrix for microorganisms to survive and contain compounds in detectable concentrations identified as having a potentially detrimental environmental impact.

The suggested recipes for LC and HC greywater loadings are easy to prepare and replicate by others in the future. All selected materials were of chemical analytical 
grade. High quantity stock solutions can be prepared and stored at $4{ }^{\circ} \mathrm{C}$ without major concern.

Throughout monitoring of the synthetic greywater properties during storage, the water quality parameters concerning their average values are chemically relatively stable. It has been noticed that only significant $(\mathrm{p}<0.05)$ fluctuations in the $\mathrm{BOD}_{5}$ for both greywater concentrations may occur. In addition, it is not recommended to store the synthetic greywater for more than two days to avoid depletion of dissolved oxygen due to development of microorganisms. Furthermore, significant changes in nitratenitrogen content might be noticed after two days of storage. 
Figure 1. Effect of storage time on the variation of (a) five-day biochemical oxygen demand $\left(\mathrm{BOD}_{5}\right)$ of low concentration synthetic greywater (LC), (b) $\mathrm{BOD}_{5}$ of high concentration synthetic greywater (HC), (c) chemical oxygen demand (COD) of LC, (d) COD of HC, (e) ammonia-nitrogen $\left(\mathrm{NH}_{4}-\mathrm{N}\right)$ of $\mathrm{LC}$, (f) $\mathrm{NH}_{4}-\mathrm{N}$ of $\mathrm{HC}$, (g) nitratenitrogen $\left(\mathrm{NO}_{3}-\mathrm{N}\right)$ of $\mathrm{LC}$, (h) $\mathrm{NO}_{3}-\mathrm{N}$ of $\mathrm{HC}$, (i) ortho-phosphate-phosphorus $\left(\mathrm{PO}_{4}-\mathrm{P}\right)$ of $\mathrm{LC}$, and (j) $\mathrm{PO}_{4}-\mathrm{P}$ of $\mathrm{HC}$ greywater.

Figure 2. Effect of storage time on the synthetic greywater characteristics (a) five-day biochemical oxygen demand, (b) chemical oxygen demand, (c) ammonia-nitrogen, (d) nitrate-nitrogen, and (e) ortho-phosphate-phosphorus. 
Table 1. Characteristics of real greywater $(\mathrm{GW})$.

Table 2. Trace element concentrations (mg/l) of real greywater (GW).

Table 3. Heavy metal concentrations (mg/l) of real greywater (GW).

Table 4a. Recipes reported for different synthetic greywater.

Table 4b. Characteristics of different synthetic greywaters proposed in Table 4a.

Table 5. Proposed ingredients for low and high strength synthetic greywaters.

Table 6. Water quality parameters after two and seven days of storage time. 


\section{References}

[1] FAO, Food and Agriculture Organization of the United Nations. Coping with water scarcity: Challenge of the twenty first century: Cairo, Egypt: FAO Regional Office for the Near East; 2007.

[2] Jefferson B, Laine A, Parsons S, et al. Technologies for domestic wastewater recycling. Urban Water. 2000;1:285-292.

[3] Surendran S, Wheatley A. Grey-water reclamation for non-potable re-use. Water Environ J. 1998;12:406-413.

[4] Eriksson E, Auffarth K, Henze M, et al. Characteristics of grey wastewater. Urban Water. 2002;4:85-104.

[5] Jeppesen B. Domestic greywater re-use: Australia's challenge for the future. Desalination. 1996;106:311-315.

[6] Al-Jayyousi OR. Greywater reuse: towards sustainable water management. Desalination. 2003;156:181-192.

[7] Christova-Boal D, Eden RE, McFarlane S. An investigation into greywater reuse for urban residential properties. Desalination. 1996;106:391-397.

[8] Emmerson G. Every drop is precious: Greywater as an alternative water source. Queensland Parliamentary Library: Brisbane; 1998.

[9] WHO, World Health Organization. Overview of greywater management health considerations. Regional Office for the Eastern Mediterranean Centre for Environmental Health Activities: Amman, Jordan; 2006.

[10] Li F, Wichmann K, Otterpohl R. Review of the technological approaches for grey water treatment and reuses. Sci Total Environ. 2009;407:3439-3449.

[11] Nolde E. Greywater reuse systems for toilet flushing in multi-storey buildings over ten years experience in Berlin. Urban Water. 2000;1:275-284.

[12] Al-Hamaiedeh H, Bino M. Effect of treated grey water reuse in irrigation on soil and plants. Desalination. 2010;256:115-119.

[13] Pidou M, Avery L, Stephenson T, et al. Chemical solutions for greywater recycling. Chemosphere. 2008;71:147-155.

[14] Ramona G, Green M, Semiat R., et al. Low strength greywater characterization and treatment by direct membrane filtration. Desalination. 2004;170:241-250.

[15] March JG, Gual M, Orozco F. Experiences on greywater re-use for toilet flushing in a hotel (Mallorca Island, Spain). Desalination. 2004;164:241-247. 
[16] Eriksson E, Srigirisetty S, Eilersen AM. Organic matter and heavy metals in grey-water sludge. Water SA. 2010;36:139-142.

[17] Nghiem LD, Oschmann N, Schäfer AI. Fouling in greywater recycling by direct ultrafiltration. Desalination. 2006;187:283-290.

[18] Houshia OJ, Abueid M, Daghlas A, et al. Characterization of grey water from country-side decentralized water treatment stations in northern Palestine. J Environ Earth Sci. 2012;2:1-8.

[19] Leal LH, Soeter AM, Kools SE, et al. Ecotoxicological assessment of greywater treatment systems with Daphnia magna and Chironomus riparius. Water Res. 2012;46:1038-1044.

[20] Gross A, Shmueli O, Ronen Z, et al. Recycled vertical flow constructed wetland (RVFCW) - a novel method of recycling greywater for irrigation in small communities and households. Chemosphere. 2007;66:916-23.

[21] Kariuki FW, Ngàng VG, Kotut K. Hydrochemical characteristics, plant nutrients and metals in household greywater and soils in Homa Bay town. The Open Environ Eng J. 2012;5:103-109.

[22] Jefferson B, Burgess JE, Pichon A, et al. Nutrient addition to enhance biological treatment of greywater. Water Res. 2001;35:2702-2710.

[23] Liu S, Butler D, Memon FA, et al. Impact of residence time during storage on potential of water saving for grey water recycling system. Water Res. 2010;44:267-277.

[24] Dixon A, Butler D, Fewkes A, et al. Measurement and modelling of quality changes in stored untreated grey water. Urban Water. 1999;1:293-306.

[25] Domenech L, Sauri D. Socio-technical transitions in water scarcity contests: Public acceptance of greywater reuse technologies in the Metropolitan Area of Barcelona. Resour Conservation Recycling. 2010;55:53-62.

[26] Schäfer AI, Nghiem LD, Oschmann N. Bisphenol A retention in the direct ultrafiltration of greywater. J Membr Sci. 2006;283:233-243.

[27] Nazim F, Meera V. Treatment of synthetic greywater using 5\% and 10\% garbage enzyme solution. Bonfring Int J Ind Eng Manag Sci. 2013;3:111-117.

[28] Diaper C, Toifl M, Storey M. Greywater technology testing protocol. CSIRO: Water for a Healthy Country National Research Flagship; 2008. 
[29] Friedler E, Kovalio R, Galil NI. On-site greywater treatment and reuse in multistorey buildings. Water Sci Technol. 2005;51:187-194.

[30] Gross A, Kaplan D, Baker K. Removal of microorganisms from domestic greywater using a recycling vertical flow constructed wetland (RVFCW). Proc Water Environ Fed. 2006;6:6133-6141.

[31] Gross A, Kaplan D, Baker K. Removal of chemical and microbiological contaminants from domestic greywater using a recycled vertical flow bioreactor (RVFB). Ecological Eng. 2007;31:107-114.

[32] Travis MJ, Wiel-Shafran A, Weisbrod N, et al. Greywater reuse for irrigation: Effect on soil properties. Sci Total Environ. 2010;408:2501-2508.

[33] Comino E, Riggio V, Rosso M. Grey water treated by a hybrid constructed wetland pilot plant under several stress conditions. Ecological Eng. 2013;53:120-125.

[34] Pinto U, Maheshwari BL, Grewal HS. Effects of greywater irrigation on plant growth, water use and soil properties. Resour Conservation Recycling. 2010;54:429-435.

[35] Winward GP, Avery LM, Frazer-Williams R, et al. A study of the microbial quality of grey water and an evaluation of treatment technologies for reuse. Ecological Eng. 2008;32:187-197.

[36] Hourlier F, Masse A, Jaouen P, et al. Formulation of synthetic greywater as an evaluation tool for wastewater recycling technologies. Environ Technol. 2010;31:215-223.

[37] Fenner RA, Komvuschara K. A new kinetic model for ultraviolet disinfection of greywater. J Environ Eng, ASCE. 2005;131:850-864.

[38] Essington ME. Soil and water chemistry: An integrative approach: CRC press; 2004.

[39] Marfil-Vega R, Suidan MT, Mills MA. Abiotic transformation of oestrogens in synthetic municipal wastewater: an alternative for treatment. Environ Pollut. 2010;158:3372-3377.

[40] Fitria D, Scholz M, Swift GM, Hutchinson SM. Impact of sludge floc size and water composition on dewaterability. Chem Eng Technol. 2014;37:471-477.

[41] Wall NA, Choppin GR. Humic acids coagulation: influence of divalent cations. Appl Geochemistry. 2003;18:1573-1582. 
[42] McBain WJ, Cornish VE, Bowden CR. CCXV-Studies of the constitution of soap in solution: sodium myristate and sodium laurate. J Chem Soc Trans. 1912;101:2042-2056.

[43] Myers D. Surfactant Science and Technology. VCH Publishers Inc.: New York, NY, USA; 1988.

[44] Zhu SN, Wang C, Yip ACK, et al. Highly effective degradation of sodium dodecyl benzene sulphonate and synthetic greywater by Fenton-like reaction over zero valent iron-based catalyst. Environ Technol. 2015;36:1423-1432.

[45] Syafalni S, Abustan I, Dahlan I, et al. Treatment of dye wastewater using granular activated carbon and zeolite filter. Mod Appl Sci. 2012;6:37-51.

[46] Chauhan AS, Bhadauria R, Singh AK, et al. Determination of lead and cadmium in cosmetic products. J Chem Pharm Res. 2010;2:92-97.

[47] Bocca B, Pino A, Alimonti A, et al. Toxic metals contained in cosmetics: a status report. Regul Toxicol Pharmacol. 2014;68:447-67.

[48] Chjnacka K, Saeid A, Michalak I, et al. Effects of local industry on heavy metals contents in human hair. Pollut J Environ Stud. 2012;21:1563-1570.

[49] APHA, AWWA. Standard methods for the examination of water and wastewater. $21^{\text {st }}$ ed. Washington, DC: American Water Works Association, and Water and Environment Federation; 2005.

[50] Maiga Y., Moyenga D., Nikiema BC, et al. Designing slanted soil system for greywater treatment for irrigation purposes in rural area of arid regions. Environ Technol. 2014;35:3020-3027.

[51] Friedler E., Kovalio R., Ben-Zvi A. Comparative study of the microbial quality of greywater treated by three on-site treatment systems. Environ Technol. 2006;27:653-663. 
1

2

3

4

5

6

7

8

9

10

11

12

13

14

15

16

17

18

19

20

21

22

23

24

25

26

27

28

29

30

31

32

33

34

35

36

37

38

39

40

41

42

43

44

45

46

47

48

49

50

51

52

53

54

55

56

57

58

59

60

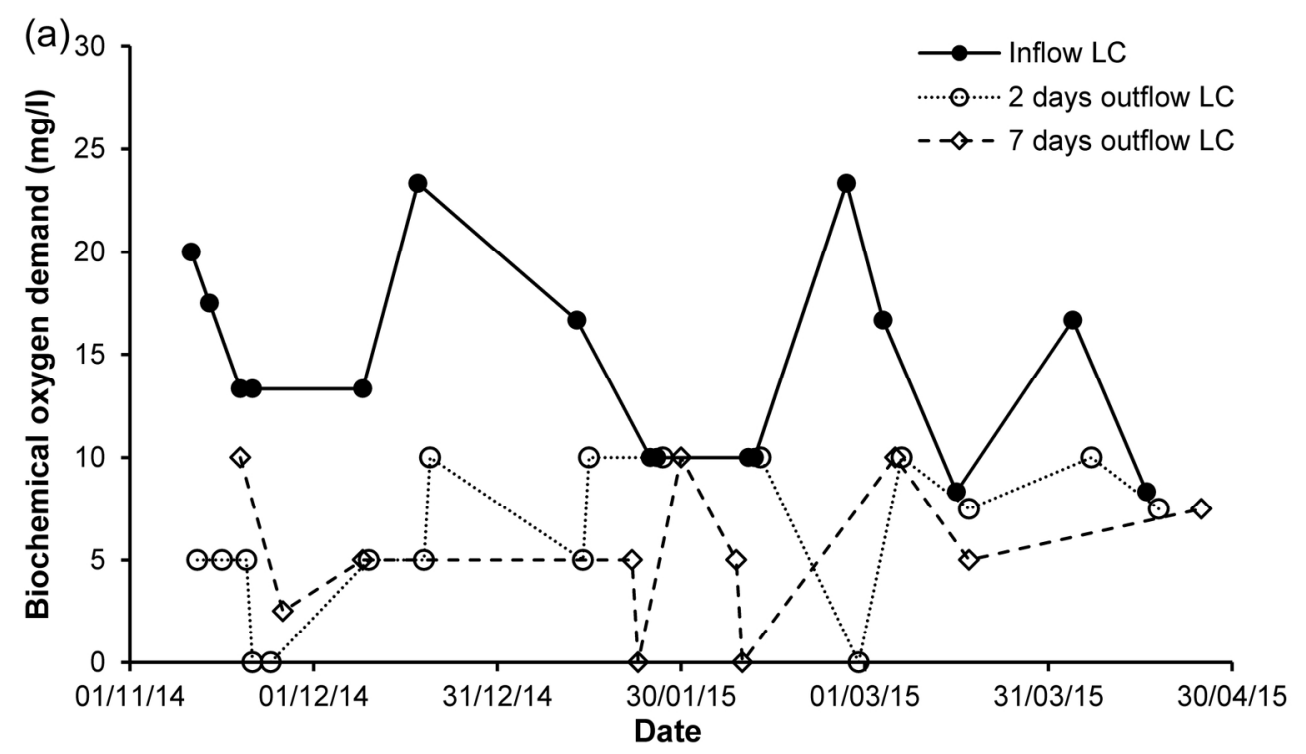

Effect of storage time on the variation of five-day biochemical oxygen demand (BOD5) of low concentration synthetic greywater (LC).

$85 \times 49 \mathrm{~mm}(600 \times 600 \mathrm{DPI})$ 


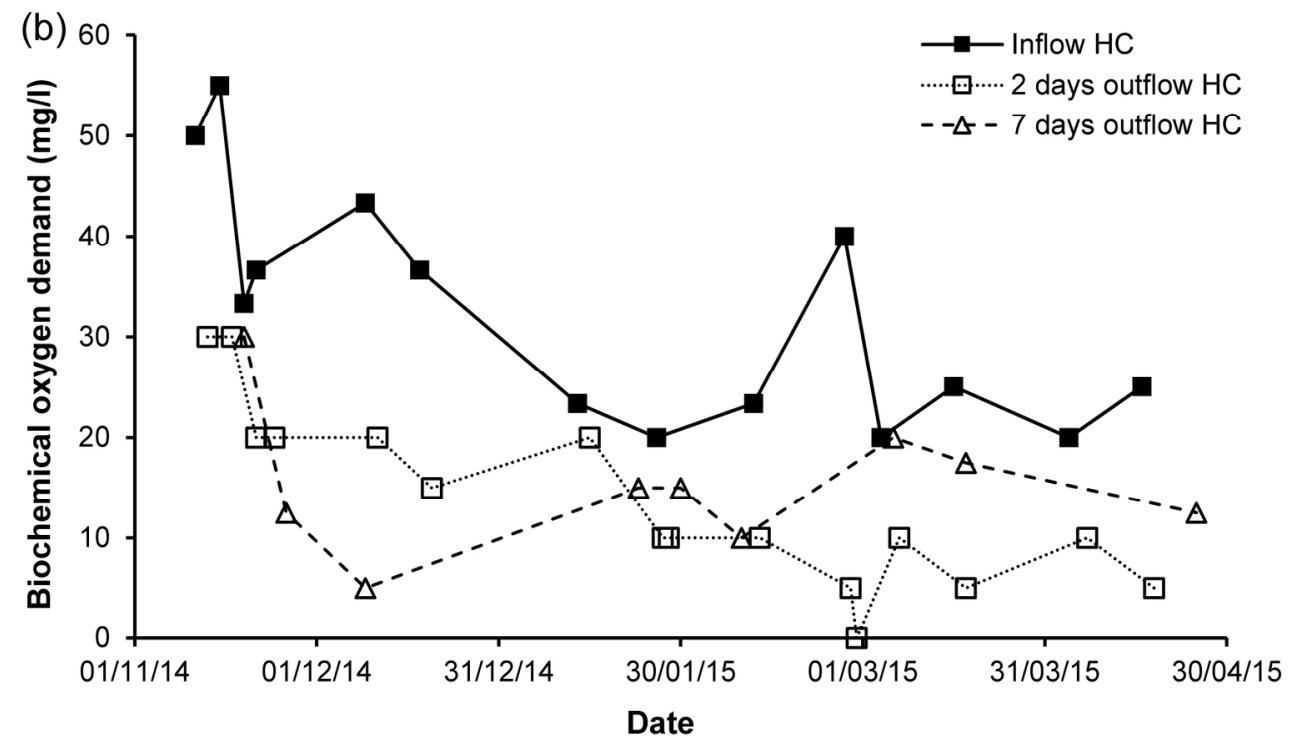

Effect of storage time on the variation of BOD5 of high concentration synthetic greywater (HC). $85 \times 49 \mathrm{~mm}(600 \times 600 \mathrm{DPI})$ 


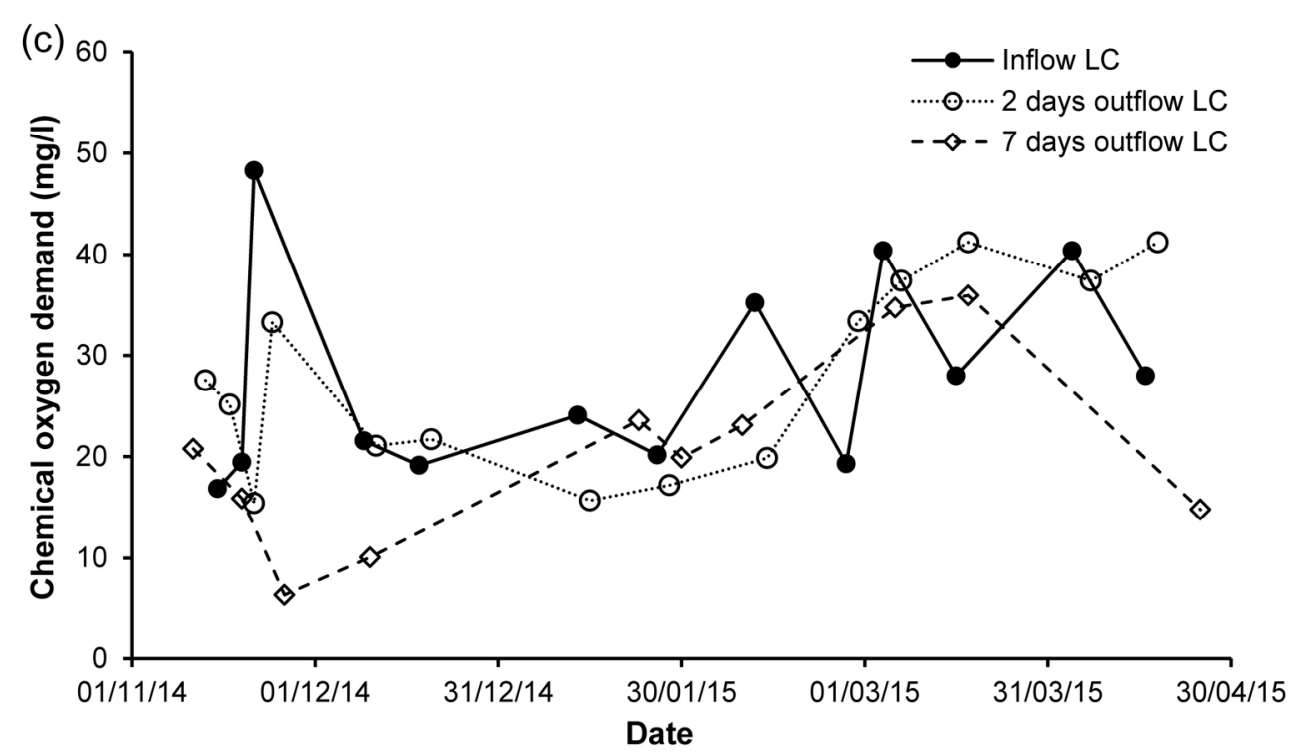

Effect of storage time on the variation of chemical oxygen demand (COD) of LC. $85 \times 49 \mathrm{~mm}(600 \times 600 \mathrm{DPI})$ 


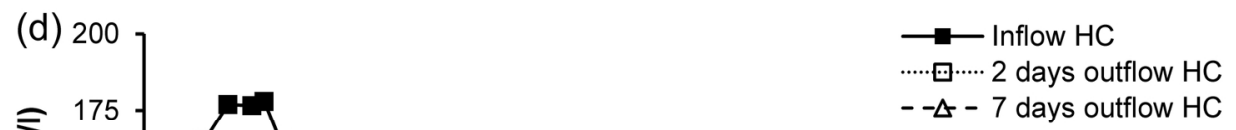




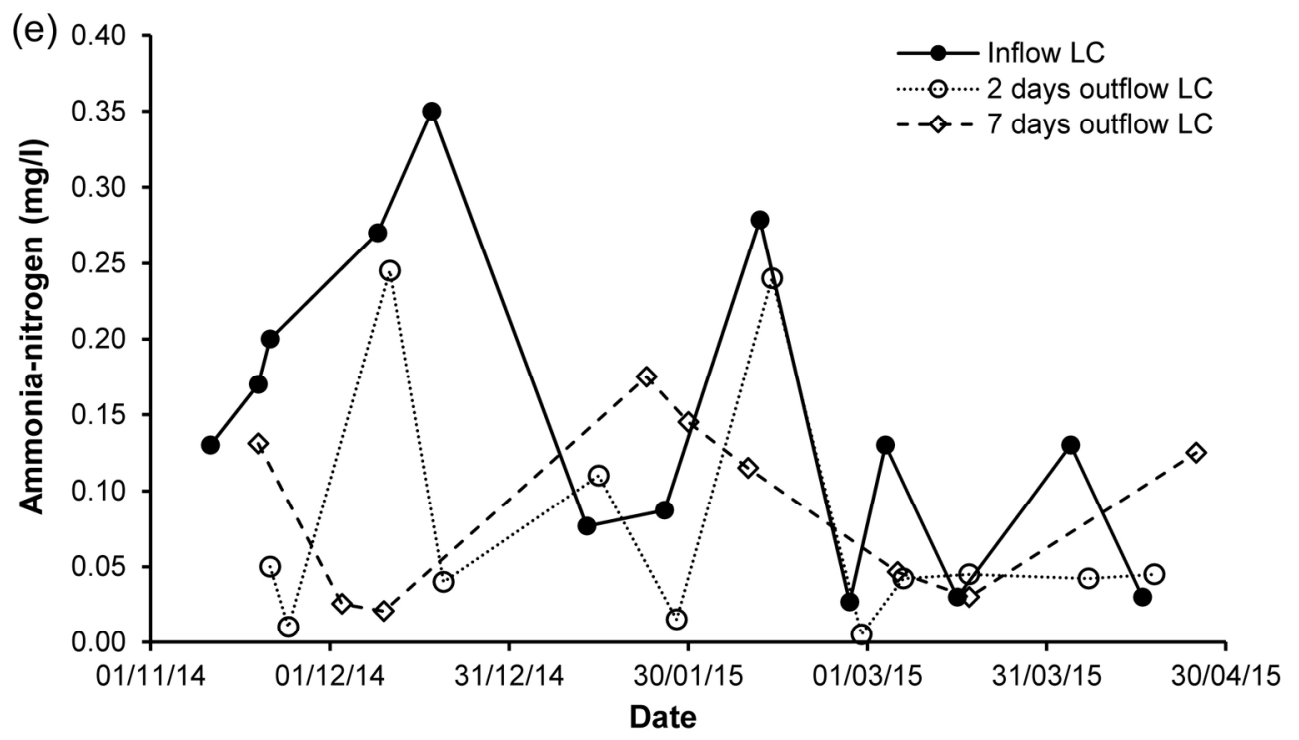

Effect of storage time on the variation of ammonia-nitrogen ( $\mathrm{NH} 4-\mathrm{N}$ ) of LC. $85 \times 49 \mathrm{~mm}(600 \times 600$ DPI $)$ 


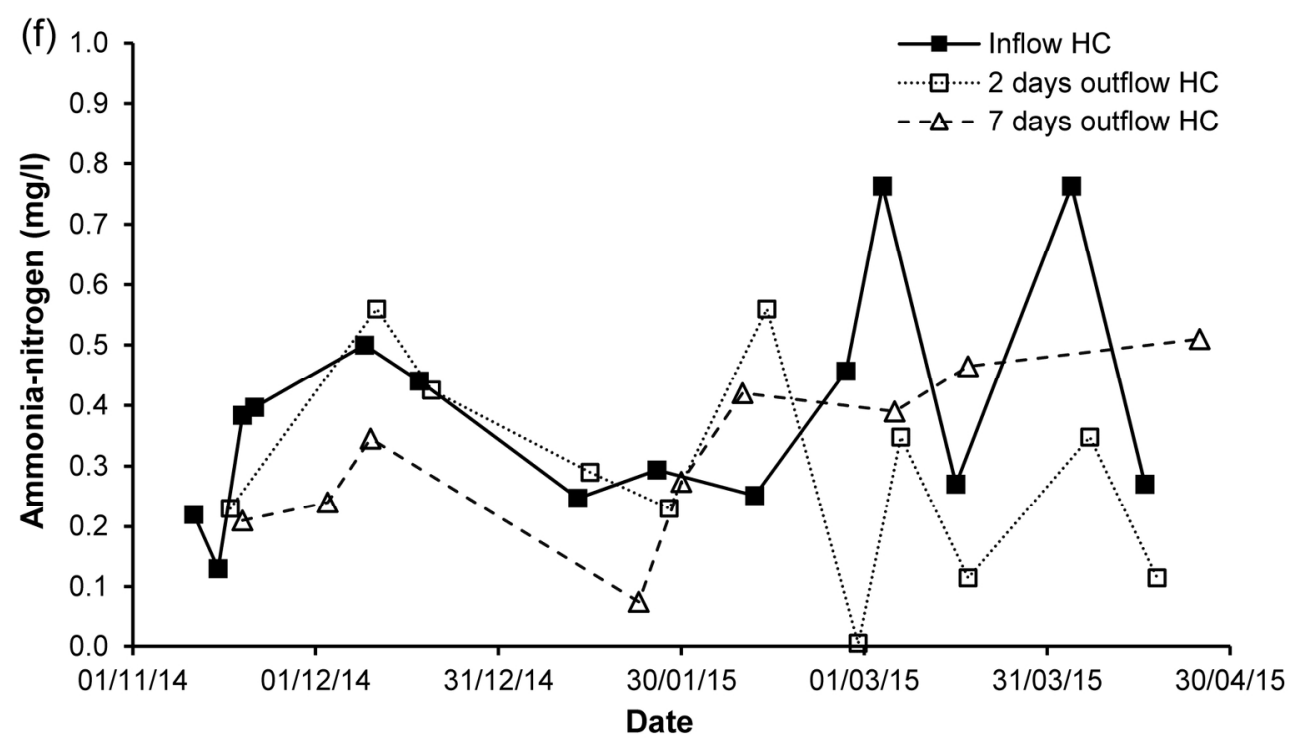

Effect of storage time on the variation of $\mathrm{NH} 4-\mathrm{N}$ of $\mathrm{HC}$. $85 \times 49 \mathrm{~mm}(600 \times 600 \mathrm{DPI})$ 


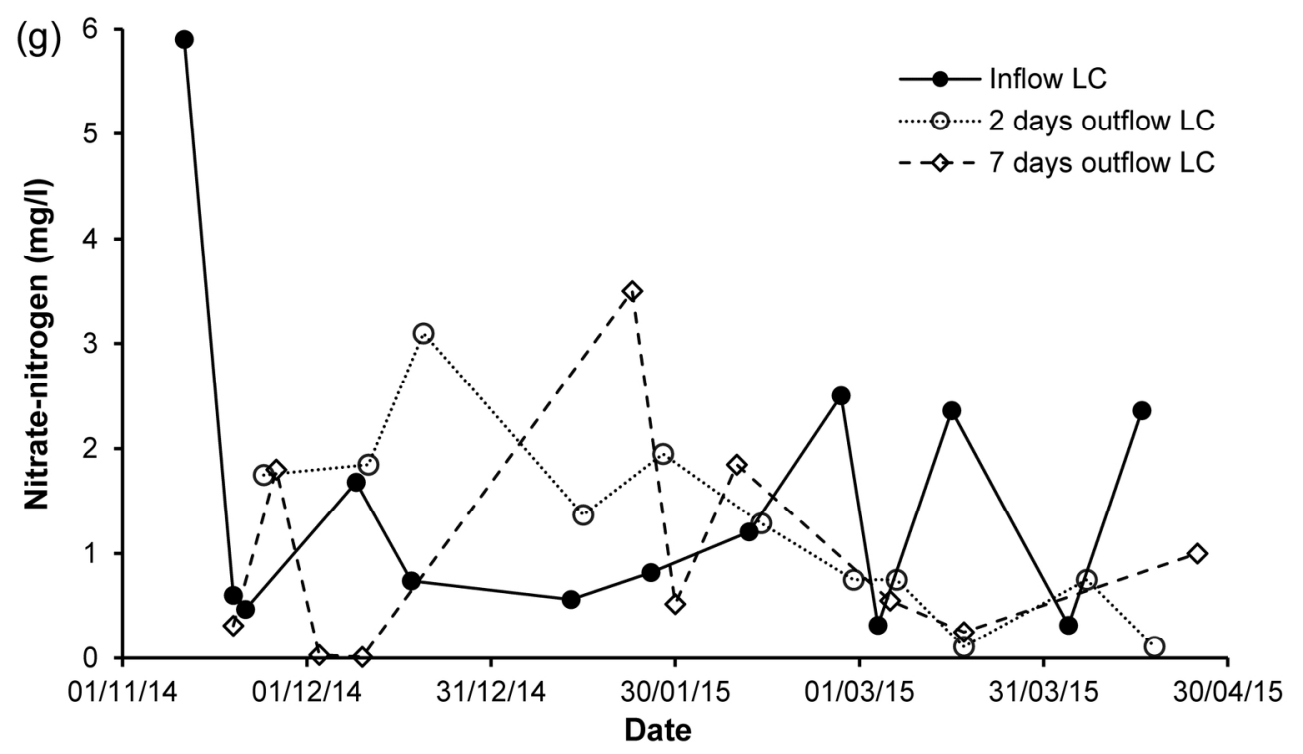

Effect of storage time on the variation of nitrate-nitrogen (NO3-N) of LC. $85 \times 49 \mathrm{~mm}(600 \times 600 \mathrm{DPI})$ 


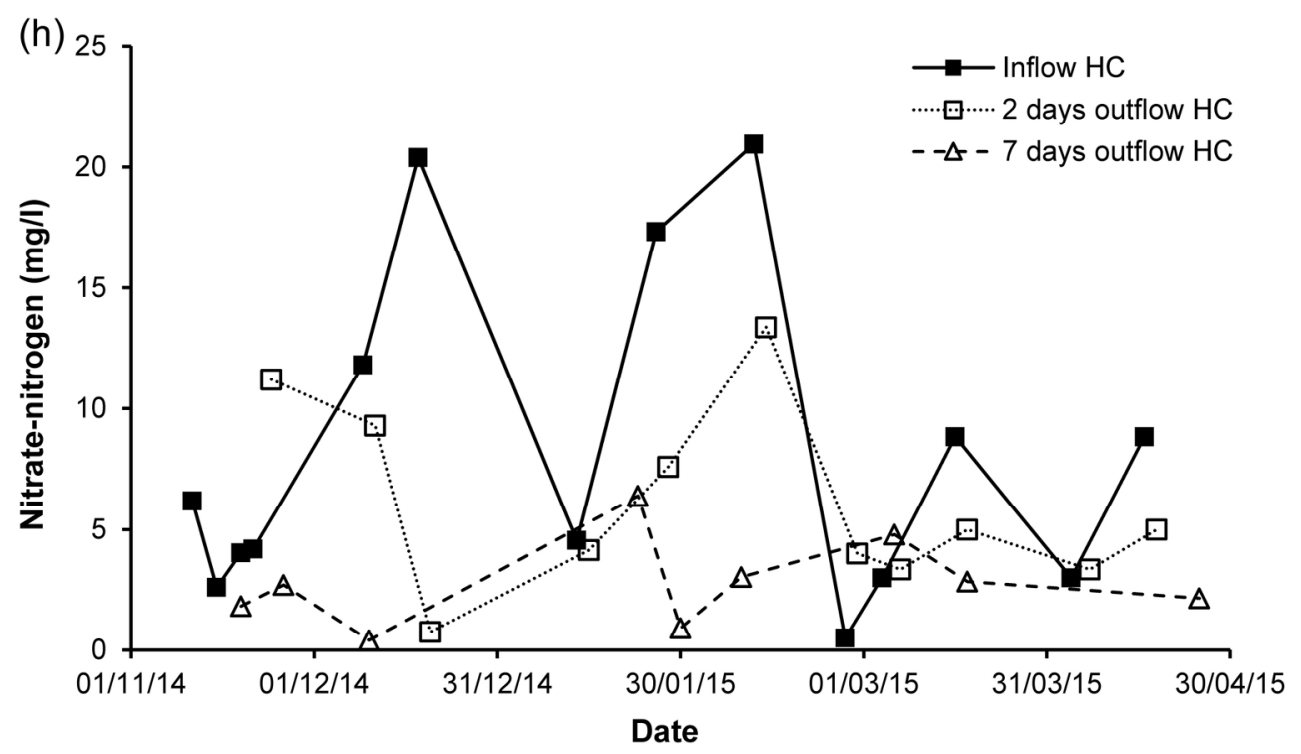

Effect of storage time on the variation of NO3-N of $\mathrm{HC}$. $85 \times 49 \mathrm{~mm}(600 \times 600 \mathrm{DPI})$ 
1

2

3

4

5

6

7

8

9

10

11

12

13

14

15

16

17

18

19

20

21

22

23

24

25

26

27

28

29

30

31

32

33

34

35

36

37

38

39

40

41

42

43

44

45

46

47

48

49

50

51

52

53

54

55

56

57

58

59

60

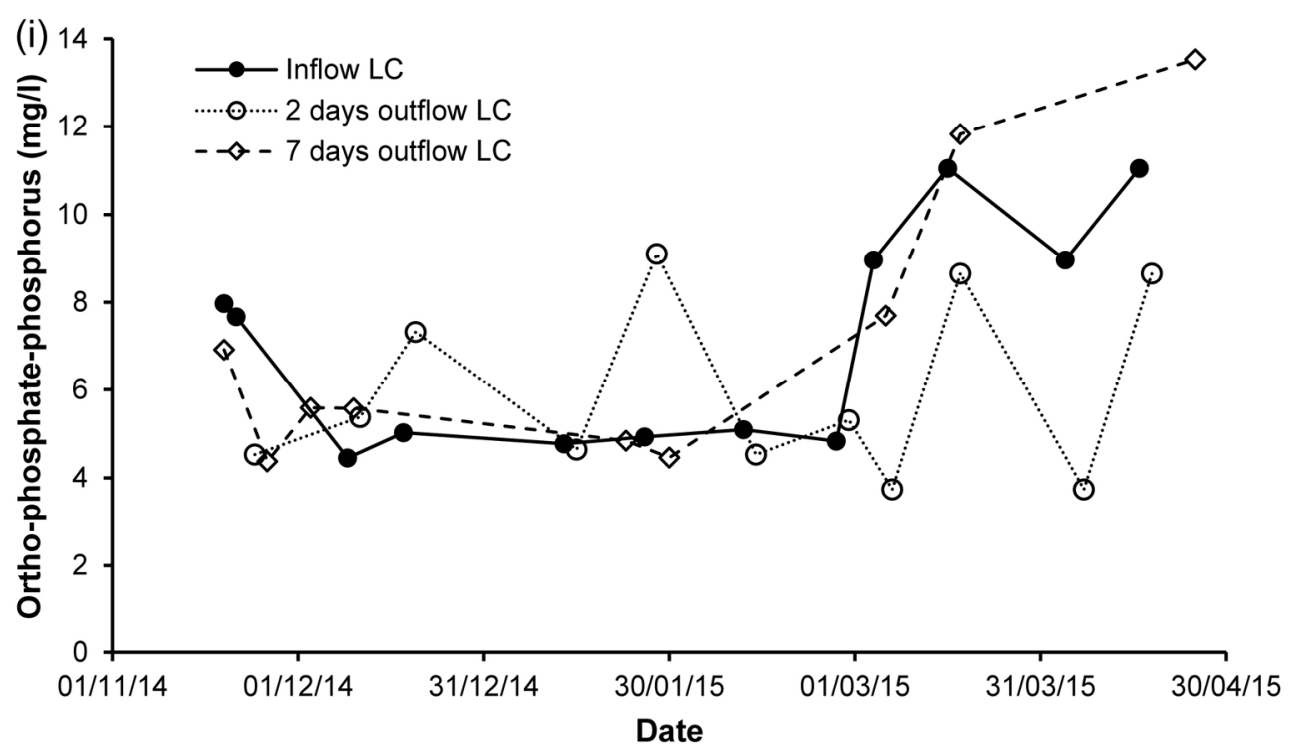

Effect of storage time on the variation of ortho-phosphate-phosphorus (PO4-P) of LC. $85 \times 49 \mathrm{~mm}(600 \times 600 \mathrm{DPI})$ 


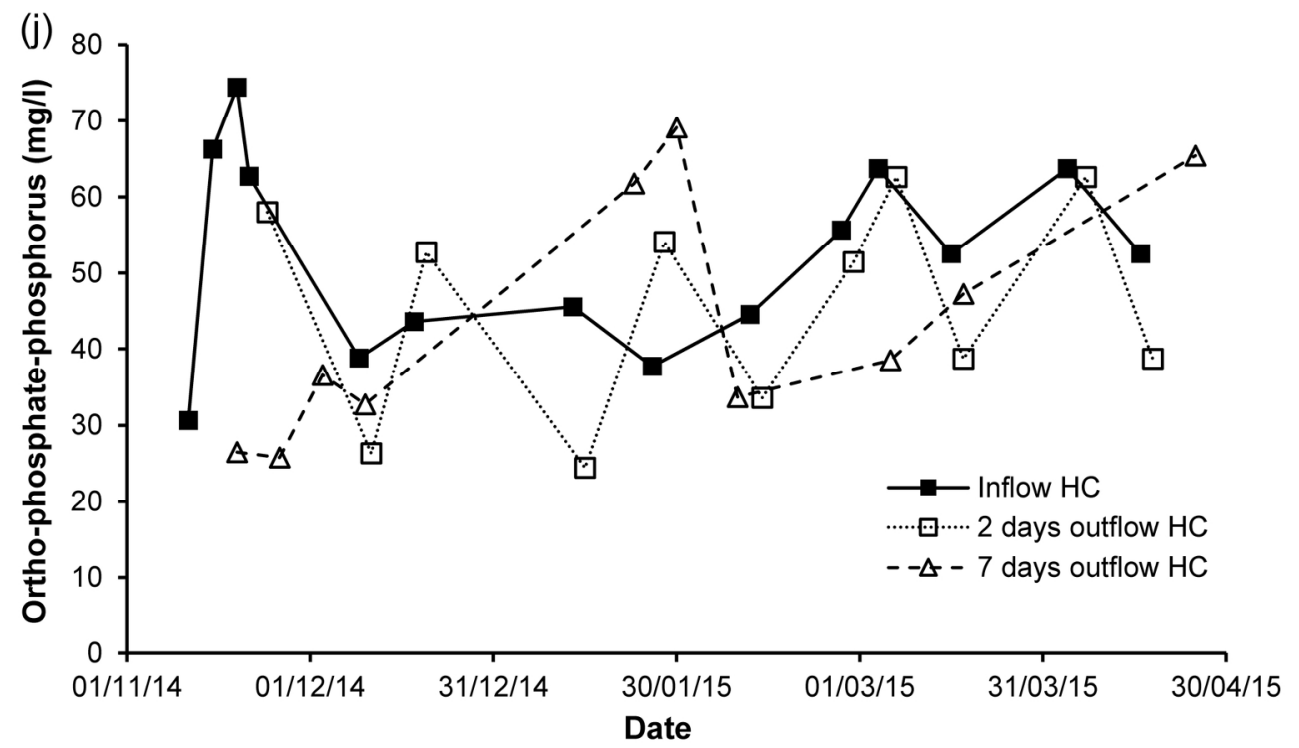

Effect of storage time on the variation of PO4-P of $\mathrm{HC}$ greywater. $85 \times 49 m m(600 \times 600$ DPI $)$ 
1

2

3

4

5

6

7

8

9

10

11

12

13

14

15

16

17

18

19

20

21

22

23

24

25

26

27

28

29

30

31

32

33

34

35

36

37

38

39

40

41

42

43

44

45

46

47

48

49

50

51

52

53

54

55

56

57

58

59

60 (a)

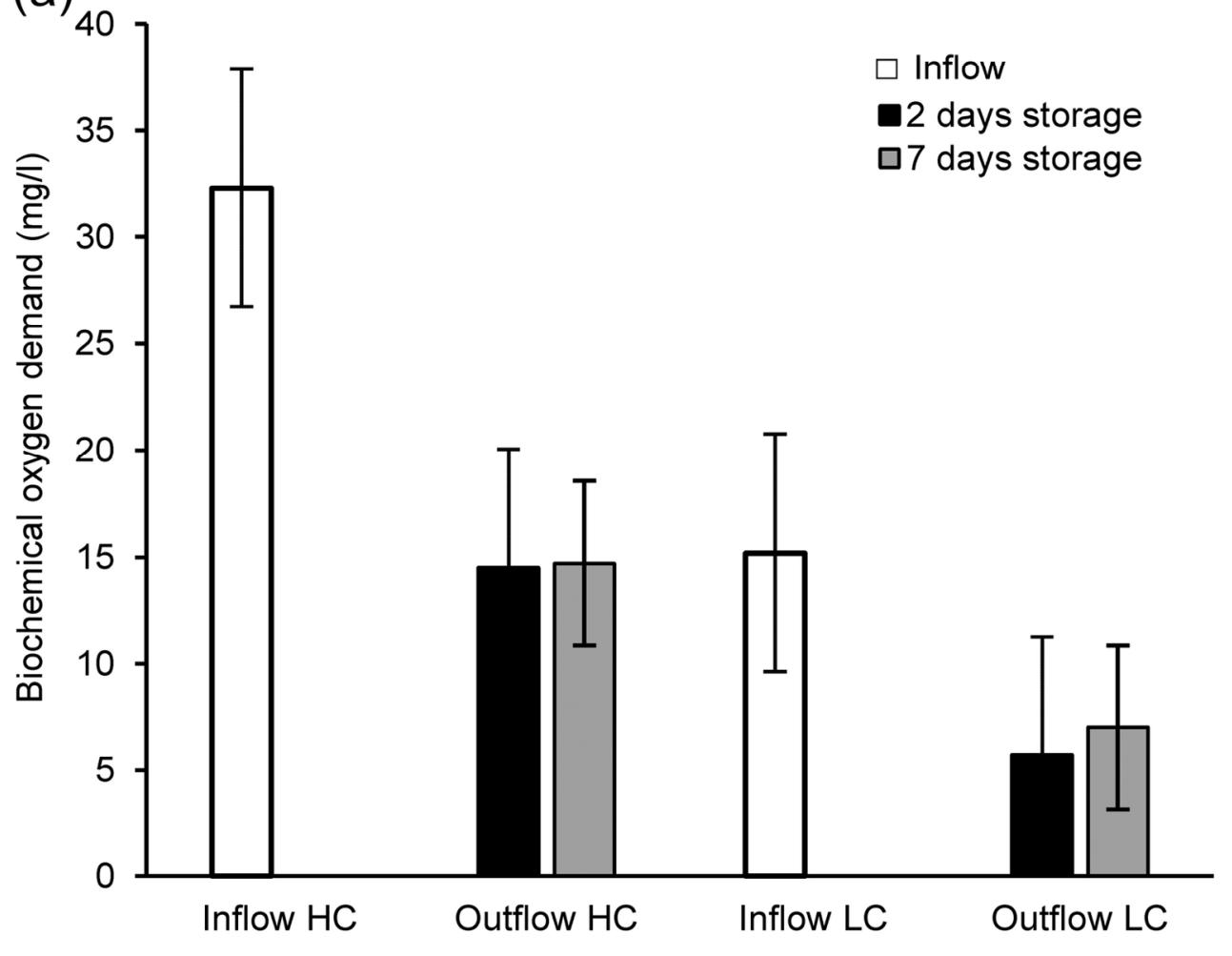

Effect of storage time on the synthetic greywater characteristics five-day biochemical oxygen demand. $70 \times 58 \mathrm{~mm}(600 \times 600 \mathrm{DPI})$ 


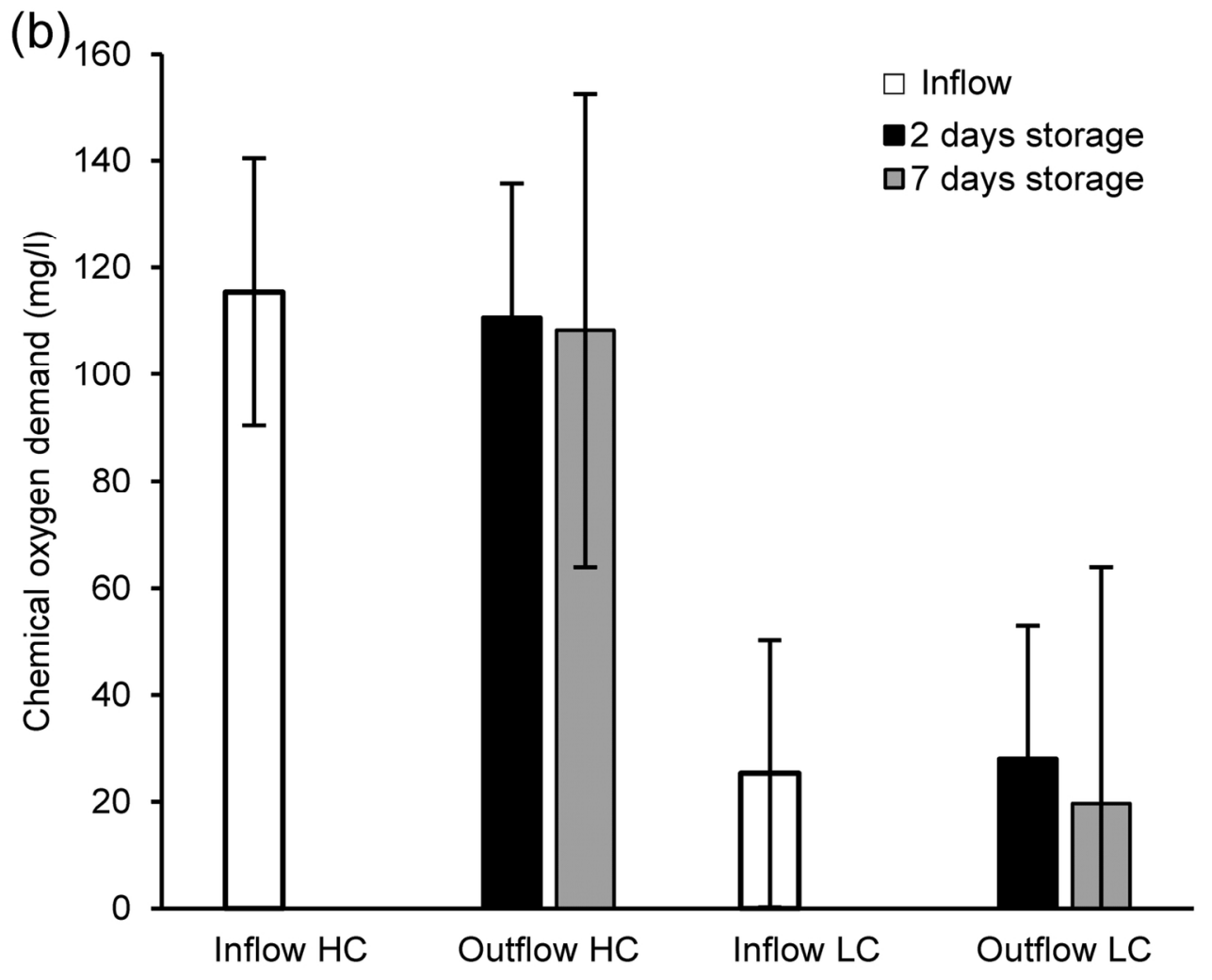

Effect of storage time on the synthetic greywater characteristics chemical oxygen demand. $70 \times 58 \mathrm{~mm}(600 \times 600 \mathrm{DPI})$ 


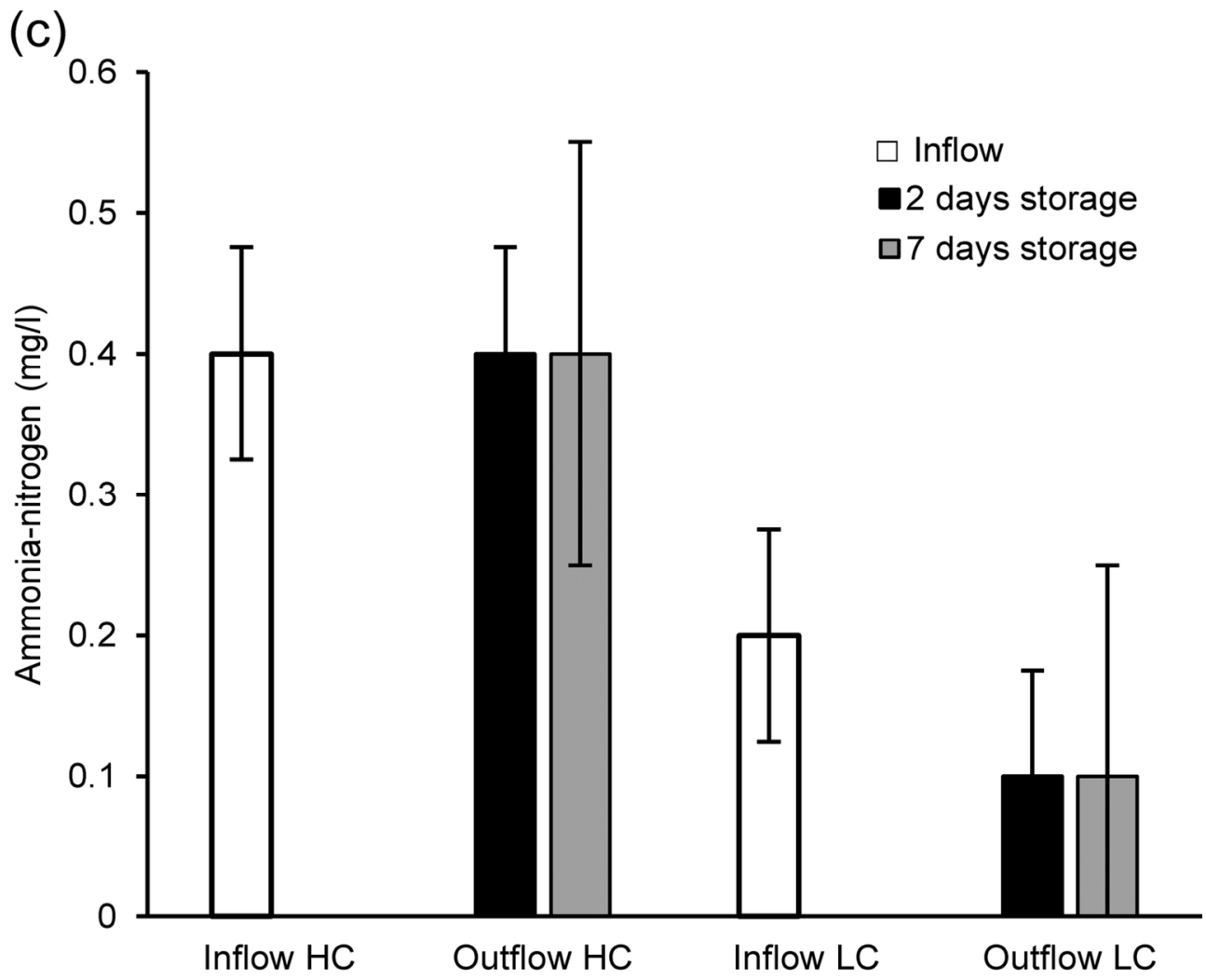

Effect of storage time on the synthetic greywater characteristics ammonia-nitrogen. $70 \times 58 \mathrm{~mm}(600 \times 600 \mathrm{DPI})$ 


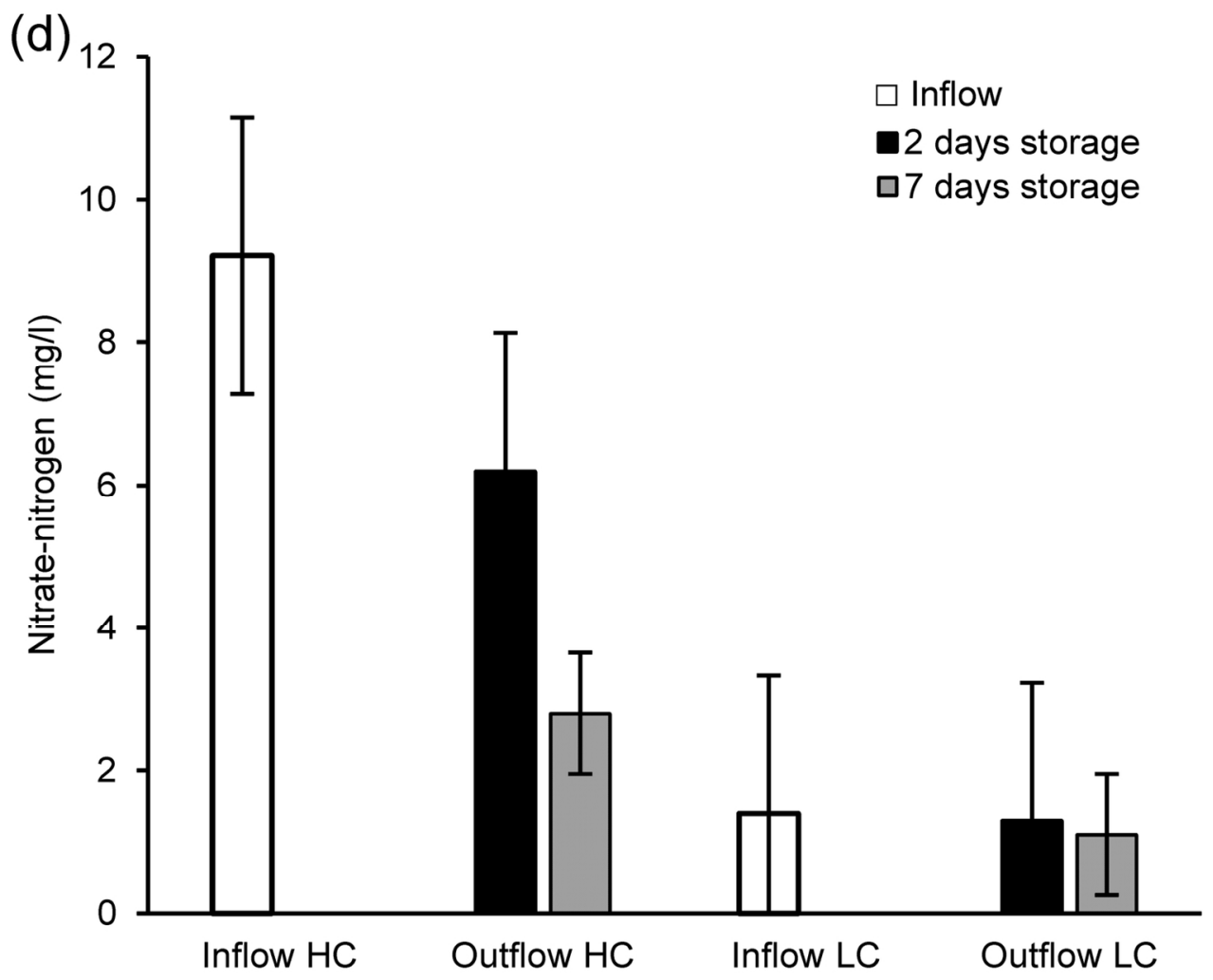

Effect of storage time on the synthetic greywater characteristics nitrate-nitrogen. $70 \times 59 \mathrm{~mm}(600 \times 600 \mathrm{DPI})$ 
1

2

3

4

5

6

7

8

9

10

11

12

13

14

15

16

17

18

19

20

21

22

23

24

25

26

27

28

29

30

31

32

33

34

35

36

37

38

39

40

41

42

43

44

45

46

47

48

49

50

51

52

53

54

55

56

57

58

59

60

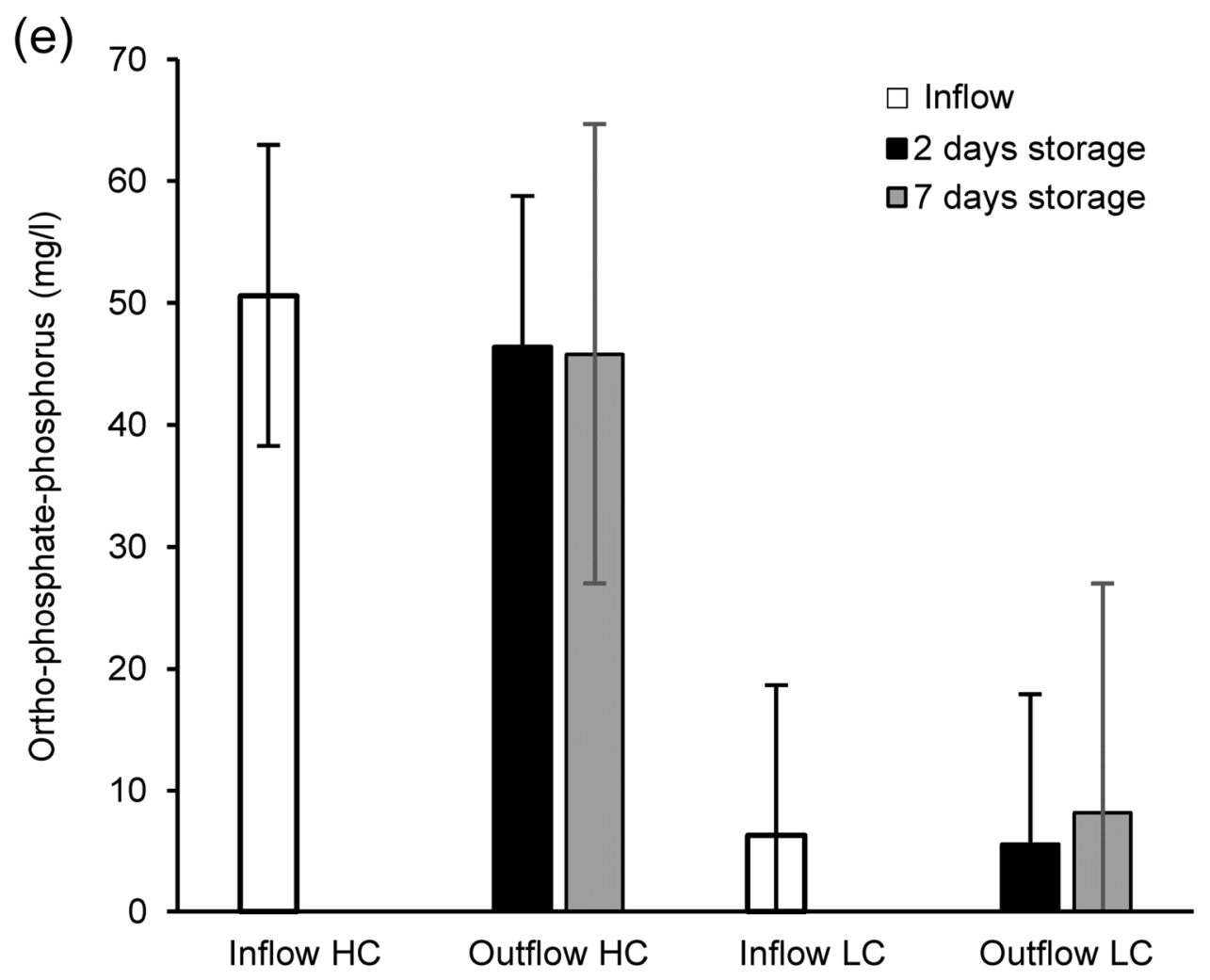

Effect of storage time on the synthetic greywater characteristics ortho-phosphate-phosphorus. $70 \times 59 \mathrm{~mm}(600 \times 600 \mathrm{DPI})$ 
Table1. Characteristics of real greywater (GW).

\begin{tabular}{|c|c|c|c|c|c|c|c|c|c|c|c|c|}
\hline Reference & Greywater source & $\begin{array}{l}\text { Temp. } \\
\left({ }^{\circ} \mathrm{C}\right)\end{array}$ & $\begin{array}{l}\mathrm{pH} \\
(-)\end{array}$ & $\begin{array}{l}\text { Turbidity } \\
\text { (NTU) }\end{array}$ & $\begin{array}{c}\mathrm{TSS} \\
(\mathrm{mg} / \mathrm{l})\end{array}$ & $\begin{array}{c}\mathrm{EC} \\
(\mu \mathrm{S} / \mathrm{cm})\end{array}$ & $\begin{array}{c}\mathrm{DO} \\
(\mathrm{mg} / \mathrm{l})\end{array}$ & $\begin{array}{l}\mathrm{BOD}_{5} \\
(\mathrm{mg} / \mathrm{l})\end{array}$ & $\begin{array}{l}\mathrm{COD} \\
(\mathrm{mg} / \mathrm{l})\end{array}$ & $\begin{array}{c}\mathrm{NH}_{4}-\mathrm{N} \\
(\mathrm{mg} / \mathrm{l})\end{array}$ & $\begin{array}{c}\mathrm{NO}_{3}-\mathrm{N} \\
(\mathrm{mg} / \mathrm{l})\end{array}$ & $\begin{array}{l}\mathrm{PO}_{4}-\mathrm{P} \\
(\mathrm{mg} / \mathrm{l})\end{array}$ \\
\hline \multirow[t]{4}{*}{ Eriksson et al. [4] } & Bathroom GW & 29 & $6.4-8.1$ & $60-240$ & $54-200$ & $82-250$ & & $76-200$ & $100-633$ & $\leq 0.1$ to 15.0 & $0.28-6.30$ & $0.94-48.80$ \\
\hline & Laundry GW & $28-32$ & $8.1-10.0$ & $14-296$ & $120-280$ & $190-1400$ & & $48-380$ & $12.8-725.0$ & $0.04-11.30$ & $0.4-2.0$ & 4-171 \\
\hline & Kitchen GW & $27-38$ & $6.3-7.4$ & & $235-720$ & & $2.2-5.8$ & $1040-1460$ & $3.8-1380$ & $0.002-23.0$ & $0.3-5.8$ & $12.7-32.0$ \\
\hline & Mixed GW & $18-38$ & $5.0-8.7$ & 15.3 to $\geq 200.0$ & & $320-20000$ & & $90-360$ & $13-549$ & $0.03-25.40$ & $0.0-4.9$ & 4-68 \\
\hline \multirow[t]{7}{*}{ Al-Jayyousi [6] } & Hand basin & & & & & & & 109 & 263 & 9.6 & & \\
\hline & Combined & & & 69 & & & & 121 & 371 & 1 & & \\
\hline & Single person & & & 14 & & & & 110 & 256 & & & \\
\hline & Single family & & & 76.5 & & & & & & 0.74 & & \\
\hline & Block of flats & & & 20 & & & & 33 & 40 & 10 & & \\
\hline & College & & & 59 & & & & 80 & 146 & 10 & & \\
\hline & Large college & & & 57 & & & & 96 & 168 & 0.8 & & \\
\hline \multirow[t]{2}{*}{ Christova-Boal et al. [7] } & Bathroom GW & 25 & $6.4-8.1$ & $60-240$ & $48-120$ & $82-250$ & & $76-200$ & & $\leq 0.1$ to 15.0 & & \\
\hline & Laundry GW & 25 & $9.3-10.0$ & $50-210$ & $88-250$ & $190-1400$ & & $48-290$ & & $\leq 0.1$ to 1.9 & & \\
\hline \multirow[t]{4}{*}{ Li et al. [10] } & Bathroom GW & & $6.4-8.1$ & $44-375$ & $7-505$ & & & $50-300$ & $100-633$ & & & \\
\hline & Laundry GW & & $7.1-10.0$ & $50-444$ & $68-465$ & & & $48-472$ & $231-2950$ & & & \\
\hline & Kitchen GW & & $5.9-7.4$ & 298 & $134-1300$ & & & $536-1460$ & $26-2050$ & & & \\
\hline & Mixed GW & & $6.3-8.1$ & $29-375$ & $25-183$ & & & $47-466$ & $100-700$ & & & \\
\hline \multirow[t]{2}{*}{ Al-Hamaiedeh and Bino [12] } & Real GW range & & $6.9-7.8$ & & $23-358$ & $157-200$ & & $110-1240$ & $92-2263$ & & $0.44-0.93$ & \\
\hline & Real GW average & & 7.2 & & 275 & 183 & & 942 & 1712 & & 0.68 & \\
\hline \multirow[t]{3}{*}{ Pidou et al. [13] } & Mixed GW LC & & $6.6-7.6$ & 35 & & & & 39 & 144 & 0.7 & 3.9 & 0.5 \\
\hline & Shower GW HC & & $7.3-7.8$ & 42 & & & & 166 & 575 & 1 & 7.5 & 1.3 \\
\hline & Real Raw GW & & & 46.6 & & & & 205 & 791 & 1.2 & 6.7 & 1.66 \\
\hline Ramona et al. [14] & Shower GW1 & & 7.5 & 23 & 29.8 & 1317 & & 78 & 170 & $1.5-3.0$ & $0.05-1.70$ & $0.02-0.19$ \\
\hline March et al. [15] & Raw GW & & $7.3-8.0$ & $5-62$ & & & & & $39-441$ & & & \\
\hline \multirow[t]{2}{*}{ Eriksson et al. [16] } & Raw GW 1 & & $7.7-8.1$ & & $51-135$ & & $2.5-4.5$ & $18-68$ & & $0.36-4.40$ & & $0.02-2.20$ \\
\hline & Raw GW 2 & & $8.2-8.3$ & & $67-390$ & & $9.3-9.5$ & $\leq 3$ & & $0.07-0.13$ & & $0.25-0.28$ \\
\hline Nghiem et al. [17] & Real GW & & $5.0-10.9$ & & & & & $33-1460$ & $3.8-1380.0$ & & & \\
\hline Houshia et al. [18] & Raw GW & & 6.1 & & & 1500 & & 126.6 & & & 38 & \\
\hline Leal et al. [19] & Raw GW & & 7.24 & & & 74.4 & & & 1476 & & $\leq 0.10$ & 2.97 \\
\hline
\end{tabular}

URL: http:/mc.manuscriptcentral.com/tent 
Table 2. Trace element concentrations (mg/l) of real greywater (GW).

\begin{tabular}{|c|c|c|c|c|c|c|c|c|c|c|}
\hline Reference & Greywater Source & Aluminium & Boron & Calcium & Potassium & Magnesium & Sodium & Sulphur & Silicon & Phosphorus \\
\hline \multirow[t]{4}{*}{ Eriksson et al. [4] } & Bathroom GW & $\leq 0.1$ & $\leq 0.1$ & $3.5-7.9$ & $1.5-5.2$ & $1.4-2.3$ & $7.4-18.0$ & $1.2-3.3$ & $3.2-4.1$ & \\
\hline & Laundry GW & $\leq 1.0-21$ & $0.1-0.5$ & $3.9-14.0$ & $1.1-17.0$ & $1.1-3.1$ & $44-480$ & $9.5-40.0$ & $3.8-49.0$ & \\
\hline & Kitchen GW & $0.67-1.8$ & & $13-30$ & $19-59$ & $3.3-7.3$ & $29-180$ & & & \\
\hline & Mixed GW & $0.10-3.55$ & & $11-35$ & 6.6 & $1.5-19.0$ & $21-230$ & & & \\
\hline \multirow[t]{2}{*}{ Christova-Boal et al. [7] } & Bathroom GW & $\leq 1.0$ & & $3.5-7.9$ & $1.5-5.2$ & $1.4-2.3$ & $7.4-18.0$ & $1.2-3.3$ & $3.2-4.1$ & $0.11-1.80$ \\
\hline & Laundry GW & $\leq 1.0-21.0$ & & $3.9-12.0$ & $1.1-17.0$ & $1.1-2.9$ & $49-480$ & $9.5-40.0$ & $3.8-49.0$ & $\begin{array}{l}0.062- \\
42.000\end{array}$ \\
\hline \multirow[t]{3}{*}{ Li et al. [10] } & Bathroom GW & 2.44 & & 33.8 & 8.1 & 5.74 & & 23.7 & & \\
\hline & Laundry GW & 0.49 & & 60.79 & $\begin{array}{c}11.20- \\
23.28\end{array}$ & 6.15 & & 19 & & \\
\hline & Kitchen GW & 0.003 & & 47.9 & 5.79 & 5.29 & & 16.3 & & \\
\hline Ramona et al. [14] & Shower GW & 0.03 & 0.14 & $71.0-93.6$ & $9.8-12.4$ & $43.2-50.0$ & $93.0-142.7$ & & & \\
\hline Nghiem et al. [17] & Real GW & & & $3.6-200.0$ & & & & & & \\
\hline Houshia et al. [18] & Raw GW & & & 89.5 & 37.3 & 132.2 & & & & \\
\hline Leal et al. [19] & Raw GW & & & 42.8 & 14.5 & 11.6 & 128 & & & \\
\hline \multirow[t]{5}{*}{ Kariuki et al. [21] } & Kitchen GW1 & & & 4.9 & 23.4 & 4.8 & 15.38 & & & \\
\hline & Laundry GW1 & & & 1.3 & 26.9 & 2.54 & 39.23 & & & \\
\hline & Bath GW2 & & & 0.96 & 10 & 0.27 & 6.15 & & & \\
\hline & Kitchen GW2 & & & 0.93 & 16.9 & 0.28 & 9.89 & & & \\
\hline & Laundry GW2 & & & 0.32 & 31.8 & 1.14 & 35.38 & & & \\
\hline Jefferson et al. [22] & Real GW & 0.003 & & 47.9 & 5.79 & 5.29 & & 16.3 & & \\
\hline
\end{tabular}


Table 3. Heavy metal concentrations $(\mathrm{mg} / \mathrm{l})$ of real greywater $(\mathrm{GW})$.

\begin{tabular}{|c|c|c|c|c|c|c|c|c|c|c|}
\hline Reference & $\begin{array}{c}\text { Greywater } \\
\text { source }\end{array}$ & Cadmium & Chromium & Copper & Iron & Manganese & Nickel & Lead & Zinc & Molybdenum \\
\hline \multirow[t]{4}{*}{ Eriksson et al. [4] } & Bathroom GW & $\begin{array}{c}0.00054- \\
0.01000\end{array}$ & & $0.06-0.12$ & $0.34-1.10$ & & & 0.003 & $\begin{array}{c}0.059- \\
6.300\end{array}$ & \\
\hline & Laundry GW & $\begin{array}{c}0.00036- \\
0.03800\end{array}$ & $\leq 0.025$ & $\leq 0.050-0.322$ & $0.29-1.00$ & 0.029 & $\leq 0.028$ & 0.033 to $\leq 0.063$ & $0.09-0.44$ & \\
\hline & Kitchen GW & $\begin{array}{c}0.00052- \\
0.00700\end{array}$ & $\leq 0.025-0.130$ & $0.05-0.26$ & $0.6-1.2$ & $0.031-0.075$ & $\leq 0.025$ & $0.005-0.140$ & $\begin{array}{c}0.096- \\
1.800\end{array}$ & \\
\hline & Mixed GW & $\leq 0.006-0.030$ & $\begin{array}{c}\leq 0.01026- \\
0.05000\end{array}$ & $0.018-0.230$ & $<0.05-4.37$ & $0.014-0.075$ & $\leq 0.015-0.050$ & $\leq 0.01-0.15$ & $\begin{array}{c}\leq 0.01- \\
1.60\end{array}$ & \\
\hline \multirow[t]{2}{*}{ Christova-Boal et al. [7] } & Bathroom GW & $\leq 0.01$ & & $0.06-0.12$ & $0.34-1.10$ & & & & $0.2-6.3$ & \\
\hline & Laundry GW & $\leq 0.01$ & & $\leq 0.05-0.27$ & $0.29-1.00$ & & & & $0.09-0.32$ & \\
\hline \multirow[t]{3}{*}{ Li et al. [10] } & Bathroom GW & & & 0.0618 & 0.36 & 0.0121 & & & 0.0644 & \\
\hline & Laundry GW & & & 0.08 & 0.11 & $\leq 0.05$ & & & 0.00 & $\leq 0.05$ \\
\hline & Kitchen GW & & & 0.006 & 0.017 & 0.04 & & & 0.03 & 0.00 \\
\hline Al-Hamaiedeh and Bino & GW Range & & & & & & & $1.00-1.31$ & & \\
\hline$[12]$ & GW Average & 0.008 & & & & & & 1.19 & & \\
\hline \multirow[t]{2}{*}{ Ramona et al. [14] } & Shower GW 1 & $\leq 0.02$ & $\leq 0.02$ & $\leq 0.02$ & 0.19 & $\leq 0.02$ & $\leq 0.02$ & $\leq 0.02$ & 0.18 & $\leq 0.02$ \\
\hline & Shower GW 2 & $\leq 0.02$ & $\leq 0.02$ & $\leq 0.02$ & 0.06 & $\leq 0.02$ & $\leq 0.02$ & $\leq 0.02$ & 0.03 & $\leq 0.02$ \\
\hline \multirow[t]{2}{*}{ Eriksson et al. [16] } & Raw GW 1 & 0.0001 & & $0.0087-0.0110$ & & & $0.007-0.039$ & $0.0025-0.0031$ & & \\
\hline & Raw GW 2 & $\begin{array}{c}\leq 0.0001- \\
0.0090\end{array}$ & & $0.0085-0.0250$ & & & $0.0055-0.0079$ & $0.0018-0.0032$ & & \\
\hline Leal et al. [19] & Raw GW & & & 0.0906 & 0.29 & & & $\leq 0.010$ & & \\
\hline \multirow[t]{5}{*}{ Kariuki et al. [21] } & Kitchen GW1 & 5.5 & 16.1 & 0.9 & 1.9 & 1.4 & & 0.9 & 6.6 & \\
\hline & Laundry GW1 & 7 & 0.9 & 1 & 3.6 & 0.4 & & 0.8 & 0.4 & \\
\hline & Bath GW2 & 10.7 & 11.1 & 2.6 & 3.8 & 0.3 & & 0.2 & 0.2 & \\
\hline & Kitchen GW2 & 10 & 11.3 & 2.3 & 9.7 & 0.2 & & 0.3 & 0.1 & \\
\hline & Laundry GW2 & 11.2 & 16.1 & 2.9 & 17.5 & 0.3 & & 0.0 & 0.7 & \\
\hline
\end{tabular}


Table 4a. Recipes reported for different synthetic greywaters.

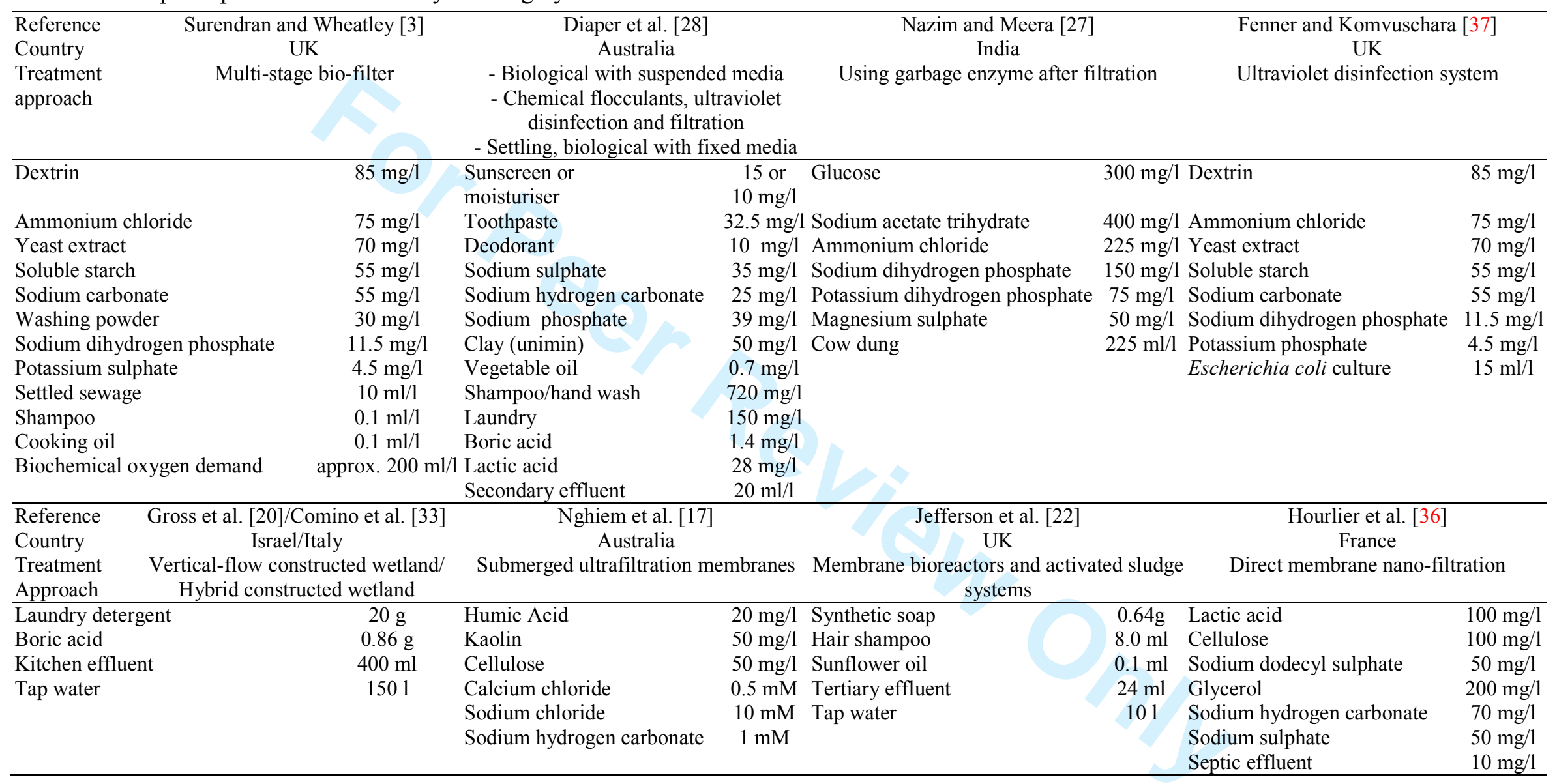


Table 4b. Characteristics of different synthetic greywaters proposed in Table 4a.

\begin{tabular}{|c|c|c|c|c|c|c|c|c|}
\hline Parameter & Unit & $\begin{array}{c}\text { Surendran and } \\
\text { Wheatley [3] }\end{array}$ & $\begin{array}{c}\text { Diaper et al. } \\
{[28]}\end{array}$ & $\begin{array}{l}\text { Nazim and } \\
\text { Meera [27] }\end{array}$ & $\begin{array}{c}\text { Gross et al. } \\
{[20]}\end{array}$ & $\begin{array}{c}\text { Comino et al. } \\
{[33]}\end{array}$ & $\begin{array}{c}\text { Nghiem et al. } \\
{[17]}\end{array}$ & $\begin{array}{l}\text { Hourlier et al. } \\
{[36]}\end{array}$ \\
\hline Biochemical oxygen demand & $\mathrm{mg} / \mathrm{l}$ & 215 & 146.7 & 192 & $28.0-688$ & & & $58-75$ \\
\hline Chemical oxygen demand & $\mathrm{mg} / \mathrm{l}$ & & 276.7 & 290 & $702-984$ & 77.4 & & $391-505$ \\
\hline Ammonia-nitrogen & $\mathrm{mg} / \mathrm{l}$ & 11 & & 9.6 & $0.1-0.5$ & & & \\
\hline Nitrate-nitrogen & $\mathrm{mg} / \mathrm{l}$ & & $<0.2$ & & $0.0-5.8$ & & & \\
\hline Nitrite-nitrogen & $\mathrm{mg} / \mathrm{l}$ & & $<0.003$ & & $0.0-1.0$ & & & \\
\hline Total nitrogen & $\mathrm{mg} / \mathrm{l}$ & & & & $25.0-45.2$ & & & \\
\hline Ortho-phosphate-phosphorus & $\mathrm{mg} / \mathrm{l}$ & 4.9 & & 110 & & & & \\
\hline Total phosphorus & $\mathrm{mg} / \mathrm{l}$ & & 17.8 & & $17.2-27.0$ & & & \\
\hline $\mathrm{pH}$ & - & & 7.4 & 6.16 & $6.3-7.0$ & 7.3 & $7.5-8.0$ & $6.29-7.29$ \\
\hline Redox potential & $\mathrm{mV}$ & & & & & & & \\
\hline Turbidity & NTU & 72 & 52.1 & & & & 140 & $4-42$ \\
\hline Total dissolved solids & $\mathrm{mg} / \mathrm{l}$ & 12.3 & & 563 & & 247.4 & & \\
\hline Total suspension solid & $\mathrm{mg} / \mathrm{l}$ & 196 & 59 & & $85-285$ & & & $41-87$ \\
\hline Total organic carbon & $\mathrm{mg} / \mathrm{l}$ & 81.8 & 62.2 & & & & & \\
\hline Dissolved organic carbon & $\mathrm{mg} / \mathrm{l}$ & & & & & & & $106-149$ \\
\hline Electronic conductivity & $\mu \mathrm{s} / \mathrm{cm}$ & & 322.2 & & $1000-1300$ & 495.1 & & $159-212$ \\
\hline Dissolved oxygen & $\mathrm{mg} / \mathrm{l}$ & & & & & & & \\
\hline Aluminium & $\mathrm{mg} / \mathrm{l}$ & & 1.6 & & & & & \\
\hline Boron & $\mathrm{mg} / \mathrm{l}$ & & & & $1.4-1.7$ & & & \\
\hline Calcium & $\mathrm{mg} / \mathrm{l}$ & & 7.6 & & & & & \\
\hline Magnesium & $\mathrm{mg} / \mathrm{l}$ & & 1.3 & & & & & \\
\hline Sodium & $\mathrm{mg} / \mathrm{l}$ & & 65.3 & & & & & \\
\hline Surfactants & $\mathrm{mg} / \mathrm{l}$ & & & & $4.7-15.6$ & & & $33.5-69.8$ \\
\hline Salinity & - & & & & & 0.1 & & \\
\hline
\end{tabular}


Table 5. Proposed ingredients for low and high strength synthetic greywaters.

\begin{tabular}{|c|c|c|c|c|c|c|}
\hline Item & Chemical name & $\begin{array}{l}\text { Chemical } \\
\text { formula }\end{array}$ & $\begin{array}{l}\text { Molar mass } \\
(\mathrm{g} / \mathrm{mol})\end{array}$ & $\begin{array}{c}\text { Low } \\
\text { concentration } \\
(\mathrm{mg} / \mathrm{l})\end{array}$ & $\begin{array}{c}\text { High } \\
\text { concentration } \\
(\mathrm{mg} / \mathrm{l})\end{array}$ & Composition percentages \\
\hline 1 & Kaolin & $\mathrm{Al}_{2} \mathrm{Si}_{2} \mathrm{O}_{5}(\mathrm{OH})_{4}$ & 258.16 & 15 & 100 & $\mathrm{Al}(20.90 \%), \mathrm{H}(1.56 \%), \mathrm{O}(55.78 \%)$ and $\mathrm{Si}(21.76 \%)$ \\
\hline 2 & Cellulose & $\left(\mathrm{C}_{6} \mathrm{H}_{10} \mathrm{O}_{5}\right)_{\mathrm{n}}$ & 162.14 & 15 & 100 & $\mathrm{C}(44.45 \%), \mathrm{H}(6.22 \%)$ and $\mathrm{O}(49.34 \%)$ \\
\hline 3 & Humic acid & $\mathrm{C}_{187} \mathrm{H}_{186} \mathrm{O}_{89} \mathrm{~N}_{9} \mathrm{~S}_{1}$ & 4015.55 & 5 & 20 & $\begin{array}{l}\mathrm{C}(55.90 \%), \mathrm{H}(4.67 \%), \mathrm{O}(35.46 \%), \mathrm{N}(4.67 \%) \text { and } \mathrm{S} \\
(0.80 \%)\end{array}$ \\
\hline 4 & Sodium chloride & $\mathrm{NaCl}$ & 58.44 & 10 & 120 & $\mathrm{Cl}(60.66 \%)$ and $\mathrm{Na}(39.34 \%)$ \\
\hline 5 & Sodium hydrogen carbonate & $\mathrm{NaHCO}_{3}$ & 84.01 & 10 & 85 & $\mathrm{C}(14.30 \%), \mathrm{H}(1.20 \%), \mathrm{Na}(27.37 \%)$ and $\mathrm{O}(57.14 \%)$ \\
\hline 6 & Calcium chloride & $\mathrm{CaCl}_{2}$ & 147.02 & 10 & 55 & $\mathrm{Ca}(36.11 \%)$ and $\mathrm{Cl}(63.89 \%)$ \\
\hline 7 & Potassium nitrate & $\mathrm{KNO}_{3}$ & 101.10 & 0 & 90 & $\mathrm{~K}(38.67 \%), \mathrm{N}(13.85 \%)$ and $\mathrm{O}(47.48 \%)$ \\
\hline 8 & Calcium nitrate & $\mathrm{Ca}\left(\mathrm{NO}_{3}\right)_{2}$ & 164.09 & 0 & 150 & $\mathrm{Ca}(24.43 \%), \mathrm{N}(17.07 \%)$ and $\mathrm{O}(58.50 \%)$ \\
\hline 9 & Magnesium sulphate & $\mathrm{MgSO}_{4}$ & 120.37 & 2 & 240 & $\mathrm{Mg}(20.19 \%), \mathrm{S}(26.64 \%)$ and $\mathrm{O}(53.17 \%)$ \\
\hline 10 & Monopotassium phosphate & $\mathrm{KH}_{2} \mathrm{PO}_{4}$ & 136.09 & 13 & 85 & $\mathrm{H}(1.48 \%), \mathrm{K}(28.73 \%), \mathrm{O}(47.03 \%)$ and $\mathrm{P}(22.76 \%)$ \\
\hline 11 & Iron(III)chloride & $\mathrm{FeCl}_{3}$ & 162.20 & 0.3 & 50.0 & $\mathrm{Fe}(34.43 \%)$ and $\mathrm{Cl}(65.57 \%)$ \\
\hline 12 & Boric acid & $\mathrm{H}_{3} \mathrm{BO}_{3}$ & 61.83 & 0.6 & 3.0 & $\mathrm{H}(4.89 \%), \mathrm{B}(17.48 \%)$ and $\mathrm{O}(77.63 \%)$ \\
\hline 13 & Manganese(II)chloride & $\mathrm{MnCl}_{2}$ & 125.84 & 0.03 & 3.20 & $\mathrm{Cl}(56.34 \%)$ and $\mathrm{Mn}(43.66 \%)$ \\
\hline 14 & Zinc sulphate & $\mathrm{ZnSO}_{4}$ & 161.44 & 0.25 & 15.00 & $\mathrm{O}(39.64 \%), \mathrm{S}(19.86 \%)$ and $\mathrm{Zn}(40.50 \%)$ \\
\hline 15 & Copper sulphate & $\mathrm{CuSO}_{4}$ & 159.61 & 0.025 & 7.000 & $\mathrm{Cu}(39.81 \%), \mathrm{O}(40.10 \%)$ and $\mathrm{S}(20.09 \%)$ \\
\hline 16 & $\begin{array}{l}\text { Ammonium molybdate } \\
\text { tetrahydrate }\end{array}$ & $\left(\mathrm{NH}_{4}\right)_{6} \mathrm{Mo}_{7} \mathrm{O}_{24}$ & 1163.94 & 0.35 & 0.35 & $\mathrm{H}(2.08 \%), \mathrm{Mo}(57.71 \%), \mathrm{N}(7.22 \%)$ and $\mathrm{O}(32.99 \%)$ \\
\hline 17 & Cadmium oxide & $\mathrm{CdO}$ & 128.41 & 0.02 & 12.50 & $\mathrm{Cd}(87.54 \%)$ and $\mathrm{O}(12.46 \%)$ \\
\hline 18 & Nickel oxide & $\mathrm{NiO}$ & 74.69 & 0.02 & 0.06 & $\mathrm{Ni}(78.58 \%)$ and $\mathrm{O}(21.42 \%)$ \\
\hline 19 & Chromium(III)nitrate & $\mathrm{CrN}_{3} \mathrm{O}_{9}$ & 99.99 & 0.045 & 70.000 & $\operatorname{Cr}(21.85 \%), \mathrm{N}(17.65 \%)$ and $\mathrm{O}(60.50 \%)$ \\
\hline 20 & Sodium sulphate & $\mathrm{Na}_{2} \mathrm{SO}_{4}$ & 142.04 & 2.60 & 25.00 & $\mathrm{Na}(32.37 \%), \mathrm{O}(45.06 \%)$ and $\mathrm{S}(22.57 \%)$ \\
\hline 21 & Sodium phosphate monobasic & $\mathrm{H}_{2} \mathrm{NaPO}_{4}$ & 119.98 & 0.00 & 250.00 & $\mathrm{H}(1.68 \%), \mathrm{Na}(19.16 \%), \mathrm{O}(53.34 \%)$ and $\mathrm{P}(25.82 \%)$ \\
\hline 22 & Lead(II)oxide & $\mathrm{Pb}_{3} \mathrm{O}_{4}$ & 685.60 & 0.16 & 1.40 & $\mathrm{~Pb}(90.67 \%)$ and $\mathrm{O}(9.33 \%)$ \\
\hline 23 & $\begin{array}{l}\text { Secondary treatment effluent } \\
\text { with microbial content }(\mathrm{ml} / \mathrm{l})\end{array}$ & - & - & 20.00 & 100.00 & - \\
\hline
\end{tabular}

Note: $\mathrm{Al}=$ aluminium, $\mathrm{H}=$ hydrogen, $\mathrm{O}=$ oxygen, $\mathrm{Si}=$ silicon, $\mathrm{C}=, \mathrm{N}=$ nitrogen, $\mathrm{S}=$ sulphur, $\mathrm{Cl}=$ chlorine, $\mathrm{Na}=$ sodium, $\mathrm{Ca}=$ calcium, $\mathrm{K}=$ potassium, $\mathrm{Mg}=$ magnesium $\mathrm{P}=$ phosphorus, $\mathrm{Fe}=$ iron, $\mathrm{B}=$ boron, $\mathrm{Mn}=$ manganese, $\mathrm{Zn}=$ zinc, $\mathrm{Cu}=$ copper, $\mathrm{Mo}=$ molybdenum, $\mathrm{Cd}=\mathrm{Cadmium}, \mathrm{Ni}=$ nickel, $\mathrm{Cr}=$ chromium, $\mathrm{Pb}=$ lead, and item 23 was not considered in this study. 
Table 6. Water quality parameters after two and seven days of storage time.

\begin{tabular}{|c|c|c|c|c|c|c|c|}
\hline Parameter & Unit & Number & Mean & Standard deviation & Minimum & Maximum & Reduction (\%) \\
\hline \multicolumn{8}{|l|}{ Inflow $(L C)$} \\
\hline Biochemical oxygen demand & $\mathrm{mg} / \mathrm{l}$ & 33 & 15.2 & 7.45 & 5.0 & 30.0 & na \\
\hline Chemical oxygen demand & $\mathrm{mg} / \mathrm{l}$ & 31 & 25.2 & 9.99 & 8.2 & 48.3 & na \\
\hline Ammonia-nitrogen & $\mathrm{mg} / \mathrm{l}$ & 30 & 0.2 & 0.11 & 0.0 & 0.5 & na \\
\hline Nitrate-nitrogen & $\mathrm{mg} / \mathrm{l}$ & 32 & 1.4 & 1.61 & 0.1 & 7.6 & na \\
\hline Ortho-phosphate-phosphorus & $\mathrm{mg} / \mathrm{l}$ & 31 & 6.3 & 2.35 & 3.8 & 12.0 & na \\
\hline $\mathrm{pH}$ & - & 33 & 6.9 & 0.37 & 6.0 & 7.9 & na \\
\hline Redox potential & $\mathrm{mV}$ & 33 & 15.7 & 53.07 & -190.2 & 65.7 & na \\
\hline Turbidity & NTU & 33 & 22.6 & 7.95 & 9.8 & 41.6 & na \\
\hline Total suspension solids & $\mathrm{mg} / \mathrm{l}$ & 33 & 40.2 & 18.70 & 10.0 & 87.0 & na \\
\hline Electronic conductivity & $\mu \mathrm{s} / \mathrm{cm}$ & 33 & 150.8 & 61.89 & 98.7 & 452.0 & na \\
\hline Dissolved oxygen & $\mathrm{mg} / \mathrm{l}$ & 33 & 10.1 & 1.53 & 7.7 & 12.2 & na \\
\hline Colour & $\mathrm{Pa} / \mathrm{Co}$ & 24 & 199.9 & 71.30 & 26.0 & 332.0 & na \\
\hline Temperature & ${ }^{\circ} \mathrm{C}$ & 33 & 17.3 & 6.37 & 6.7 & 27.0 & na \\
\hline \multicolumn{8}{|l|}{ 2-day outflow (LC) } \\
\hline Biochemical oxygen demand & $\mathrm{mg} / \mathrm{l}$ & 21 & 5.7 & 3.96 & 0.0 & 10.0 & 62.3 \\
\hline Chemical oxygen demand & $\mathrm{mg} / 1$ & 21 & 27.9 & 10.26 & 2.7 & 41.9 & -10.8 \\
\hline Ammonia-nitrogen & $\mathrm{mg} / \mathrm{l}$ & 19 & 0.1 & 0.09 & 0.0 & 0.3 & 45.2 \\
\hline Nitrate-nitrogen & $\mathrm{mg} / \mathrm{l}$ & 19 & 1.3 & 0.80 & 0.1 & 3.1 & 10.4 \\
\hline Ortho-phosphate-phosphorus & $\mathrm{mg} / \mathrm{l}$ & 19 & 5.6 & 2.04 & 3.5 & 10.9 & 11.4 \\
\hline $\mathrm{pH}$ & - & 48 & 7.2 & 0.70 & 6.3 & 10.1 & na \\
\hline Redox potential & $\mathrm{mV}$ & 48 & 17.5 & 30.68 & -116.1 & 51.0 & na \\
\hline Turbidity & NTU & 48 & 21.3 & 7.81 & 2.9 & 35.4 & 5.5 \\
\hline Total suspension solids & $\mathrm{mg} / \mathrm{l}$ & 48 & 30.8 & 12.92 & 13.0 & 76.0 & 23.4 \\
\hline Electronic conductivity & $\mu \mathrm{s} / \mathrm{cm}$ & 48 & 128.4 & 23.57 & 79.0 & 215.0 & na \\
\hline Dissolved oxygen & $\mathrm{mg} / \mathrm{l}$ & 48 & 10.7 & 0.94 & 8.8 & 12.6 & -6.3 \\
\hline Colour & $\mathrm{Pa} / \mathrm{Co}$ & 36 & 156.0 & 51.13 & 34.0 & 265.0 & 22.0 \\
\hline Temperature & ${ }^{\circ} \mathrm{C}$ & 48 & 16.0 & 4.85 & 5.3 & 21.8 & na \\
\hline \multicolumn{8}{|l|}{ 7-day outflow (LC) } \\
\hline Biochemical oxygen demand & $\mathrm{mg} / \mathrm{l}$ & 15 & 7.0 & 6.21 & 0.0 & 20.0 & 54.0 \\
\hline Chemical oxygen demand & $\mathrm{mg} / \mathrm{l}$ & 22 & 19.6 & 9.83 & 6.0 & 36.7 & 22.2 \\
\hline Ammonia-nitrogen & $\mathrm{mg} / \mathrm{l}$ & 18 & 0.1 & 0.07 & 0.0 & 0.3 & 45.2 \\
\hline Nitrate-nitrogen & $\mathrm{mg} / \mathrm{l}$ & 17 & 1.1 & 1.27 & 0.0 & 4.0 & 21.4 \\
\hline Ortho-phosphate-phosphorus & $\mathrm{mg} / 1$ & 17 & 8.2 & 6.03 & 2.6 & 25.7 & -29.4 \\
\hline $\mathrm{pH}$ & - & 44 & 7.2 & 0.60 & 6.4 & 8.9 & na \\
\hline Redox potential & $\mathrm{mV}$ & 44 & 18.3 & 26.66 & -56.4 & 53.2 & na \\
\hline Turbidity & NTU & 44 & 20.1 & 5.71 & 12.6 & 34.1 & 11.1 \\
\hline Total suspension solids & $\mathrm{mg} / 1$ & 44 & 31.0 & 9.52 & 18.0 & 56.0 & 22.9 \\
\hline Electronic conductivity & $\mu \mathrm{s} / \mathrm{cm}$ & 48 & 143.0 & 38.83 & 97.7 & 263.0 & na \\
\hline Dissolved oxygen & $\mathrm{mg} / \mathrm{l}$ & 48 & 11.5 & 0.84 & 10.4 & 14.3 & -13.9 \\
\hline Colour & $\mathrm{Pa} / \mathrm{Co}$ & 36 & 171.5 & 33.14 & 128.0 & 258.0 & 14.2 \\
\hline Temperature & ${ }^{\circ} \mathrm{C}$ & 48 & 14.1 & 3.87 & 6.7 & 20.0 & na \\
\hline \multicolumn{8}{|l|}{ Inflow $(H C)$} \\
\hline Biochemical oxygen demand & $\mathrm{mg} / \mathrm{l}$ & 33 & 32.3 & 12.81 & 10.0 & 60.0 & na \\
\hline Chemical oxygen demand & $\mathrm{mg} / \mathrm{l}$ & 30 & 115.4 & 39.57 & 63.9 & 189.0 & na \\
\hline Ammonia-nitrogen & $\mathrm{mg} / \mathrm{l}$ & 30 & 0.4 & 0.18 & 0.1 & 0.8 & na \\
\hline Nitrate-nitrogen & $\mathrm{mg} / \mathrm{l}$ & 32 & 9.2 & 7.81 & 0.2 & 29.8 & na \\
\hline Ortho-phosphate-phosphorus & $\mathrm{mg} / \mathrm{l}$ & 30 & 50.6 & 13.06 & 30.7 & 92.6 & na \\
\hline $\mathrm{pH}$ & - & 33 & 8.1 & 1.93 & 5.4 & 11.5 & na \\
\hline Redox potential & $\mathrm{mV}$ & 33 & -29.3 & 89.61 & -182.1 & 97.9 & na \\
\hline Turbidity & NTU & 33 & 184.6 & 50.34 & 18.3 & 285.0 & na \\
\hline Total suspension solids & $\mathrm{mg} / \mathrm{l}$ & 33 & 317.5 & 54.73 & 190.0 & 473.0 & na \\
\hline Electronic conductivity & $\mu \mathrm{s} / \mathrm{cm}$ & 33 & 936.8 & 156.16 & 617.0 & 1180.0 & na \\
\hline Dissolved oxygen & $\mathrm{mg} / 1$ & 33 & 10.0 & 1.69 & 6.9 & 12.6 & na \\
\hline Colour & $\mathrm{Pa} / \mathrm{Co}$ & 27 & 1427.3 & 444.54 & 787.0 & 2499.0 & na \\
\hline Temperature & ${ }^{\circ} \mathrm{C}$ & 33 & 17.6 & 6.58 & 6.5 & 27.8 & na \\
\hline
\end{tabular}


Table 6 (cont.)

2-day oufflow (HC)

\begin{tabular}{|c|c|c|c|c|c|c|c|}
\hline Biochemical oxygen demand & $\mathrm{mg} / 1$ & 19 & 14.5 & 8.48 & 0.0 & 30.0 & 55.2 \\
\hline Chemical oxygen demand & $\mathrm{mg} / \mathrm{l}$ & 21 & 110.7 & 28.63 & 43.3 & 164.0 & 4.1 \\
\hline Ammonia-nitrogen & $\mathrm{mg} / \mathrm{l}$ & 19 & 0.4 & 0.26 & 0.0 & 0.9 & 6.8 \\
\hline Nitrate-nitrogen & $\mathrm{mg} / 1$ & 20 & 6.2 & 4.18 & 0.5 & 15.0 & 32.8 \\
\hline Ortho-phosphate-phosphorus & $\mathrm{mg} / \mathrm{l}$ & 20 & 46.5 & 14.37 & 23.7 & 70.1 & 8.2 \\
\hline $\mathrm{pH}$ & - & 48 & 8.3 & 1.35 & 5.6 & 9.8 & na \\
\hline Redox potential & $\mathrm{mV}$ & 48 & -28.4 & 60.63 & -107.6 & 88.6 & na \\
\hline Turbidity & NTU & 48 & 215.7 & 49.45 & 111.0 & 341.0 & -16.9 \\
\hline Total suspension solid & $\mathrm{mg} / 1$ & 48 & 345.0 & 48.49 & 229.0 & 447.0 & -8.7 \\
\hline Electronic conductivity & $\mu \mathrm{s} / \mathrm{cm}$ & 48 & 948.3 & 105.86 & 627.0 & 1196.0 & na \\
\hline Dissolved oxygen & $\mathrm{mg} / 1$ & 48 & 10.3 & 0.78 & 9.0 & 12.1 & -3.0 \\
\hline Colour & $\mathrm{Pa} / \mathrm{Co}$ & 36 & 1697.0 & 292.83 & 1121.0 & 2311.0 & -18.9 \\
\hline Temperature & ${ }^{\circ} \mathrm{C}$ & 48 & 17.0 & 4.94 & 6.0 & 21.5 & na \\
\hline \multicolumn{8}{|l|}{ 7-day outflow $(\mathrm{HC})$} \\
\hline Biochemical oxygen demand & $\mathrm{mg} / \mathrm{l}$ & 15 & 14.7 & 6.40 & 5.0 & 30.0 & 54.5 \\
\hline Chemical oxygen demand & $\mathrm{mg} / \mathrm{l}$ & 24 & 108.3 & 24.47 & 67.2 & 159.5 & 6.2 \\
\hline Ammonia-nitrogen & $\mathrm{mg} / 1$ & 16 & 0.4 & 0.19 & 0.0 & 0.8 & 0.01 \\
\hline Nitrate-nitrogen & $\mathrm{mg} / \mathrm{l}$ & 18 & 2.8 & 2.24 & 0.4 & 9.3 & 69.6 \\
\hline Ortho-phosphate-phosphorus & $\mathrm{mg} / \mathrm{l}$ & 17 & 45.8 & 18.23 & 20.3 & 79.4 & 9.5 \\
\hline $\mathrm{pH}$ & - & 48 & 8.1 & 1.20 & 5.9 & 9.8 & na \\
\hline Redox potential & $\mathrm{mV}$ & 48 & -27.4 & 57.02 & -108.3 & 78.1 & na \\
\hline Turbidity & NTU & 48 & 209.3 & 38.14 & 122.0 & 281.0 & -13.4 \\
\hline Total suspension solid & $\mathrm{mg} / 1$ & 48 & 322.5 & 73.45 & 3.1 & 434.0 & -1.6 \\
\hline Electronic conductivity & $\mu \mathrm{s} / \mathrm{cm}$ & 48 & 1105.6 & 351.09 & 668.0 & 2460.0 & na \\
\hline Dissolved oxygen & $\mathrm{mg} / \mathrm{l}$ & 48 & 10.9 & 0.72 & 9.4 & 12.0 & -9.0 \\
\hline Colour & $\mathrm{Pa} / \mathrm{Co}$ & 36 & 1882.8 & 409.34 & 1119.0 & 2889.0 & -31.9 \\
\hline Temperature & ${ }^{\circ} \mathrm{C}$ & 48 & 15.7 & 3.49 & 8.4 & 20.8 & na \\
\hline
\end{tabular}

Notes: $\mathrm{LC}=$ low concentration synthetic greywater, NTU = nephelometric turbidity unit, na = not applicable, $\mathrm{HC}=$ high concentration synthetic greywater. 


\begin{tabular}{lccc}
\multicolumn{3}{c}{ Concentrations of Proposed Synthetic Greywater } \\
\hline Parameters & Unit & \multicolumn{2}{c}{ Synthetic greywater } \\
\cline { 3 - 4 } & & Low: range (mean) & High: range (mean) \\
\hline Biochemical oxygen demand & $\mathrm{mg} / \mathrm{l}$ & $50(15.2)$ & $10-60(32.3)$ \\
Chemical oxygen demand & $\mathrm{mg} / \mathrm{l}$ & $8-48(25.2)$ & $64-189(115.4)$ \\
Ammonia-nitrogen & $\mathrm{mg} / \mathrm{l}$ & $0.0-0.5(0.2)$ & $0.1-0.8(0.4)$ \\
Nitrate-nitrogen & $\mathrm{mg} / \mathrm{l}$ & $0.1-7.6(1.4)$ & $0.2-29.8(9.2)$ \\
Ortho-phosphate-phosphorus & $\mathrm{mg} / \mathrm{l}$ & $3.8-12.0(6.3)$ & $30-92(50.6)$ \\
$\mathrm{pH}$ & - & $6-8(6.9)$ & $5-12(8.1)$ \\
Redox potential & $\mathrm{mV}$ & $-190-66(15.7)$ & $-182-98(-29.3)$ \\
Turbidity & $\mathrm{NTU}$ & $10-42(22.6)$ & $18-285(184.6)$ \\
Total suspension solids & $\mathrm{mg} / \mathrm{l}$ & $10-87(40.2)$ & $190-473(317.5)$ \\
Electronic conductivity & $\mu \mathrm{cm} / \mathrm{cm}$ & $99-452(150.8)$ & $617-1180(936.8)$ \\
Dissolved oxygen & $\mathrm{mg} / \mathrm{l}$ & $8-12(10.1)$ & $7-13(10)$ \\
Colour & $\mathrm{Pa} / \mathrm{Co}$ & $26-332(200)$ & $787-2499(1427.3)$ \\
\hline *nephelometric turbidity unit. & & &
\end{tabular}

